\title{
Geometallurgy-A Route to More Resilient Mine Operations
}

\author{
Simon C. Dominy ${ }^{1,2}, * \mathbb{C}$, Louisa $\mathrm{O}^{\prime}$ Connor $^{2}$, Anita Parbhakar-Fox ${ }^{1,3}$, Hylke J. Glass ${ }^{1}$ (i) \\ and Saranchimeg Purevgerel ${ }^{4,5}$ \\ 1 Minerals Engineering Research Group, Camborne School of Mines, University of Exeter, Penryn, \\ Cornwall TR10 9FE, UK; anita.parbhakar@utas.edu.au (A.P.-F.); h.j.glass@exeter.ac.uk (H.J.G.) \\ 2 Department of Mining and Metallurgical Engineering, Western Australian School of Mines, \\ Curtin University, Bentley, WA 6102, Australia; louisa.oconnor@curtin.edu.au \\ 3 ARC Research Hub for Transforming the Mining Value Chain, University of Tasmania, Churchill Avenue, \\ Hobart, TAS 7005, Australia \\ 4 Department of Mineral and Energy Economics, Western Australian School of Mines, Curtin University, \\ Murray Street, Perth, WA 6000, Australia; p.saranchimeg@msaglobal.net \\ 5 MSA Global LLC, Bayanzurkh District, Ulaanbaatar 13370, Mongolia \\ * Correspondence: s.dominy@e3geomet.com
}

Received: 29 September 2018; Accepted: 27 November 2018; Published: 1 December 2018

\begin{abstract}
Geometallurgy is an important addition to any evaluation project or mining operation. As an integrated approach, it establishes 3D models which enable the optimisation of net present value and effective orebody management, while minimising technical and operational risk to ultimately provide more resilient operations. Critically, through spatial identification of variability, it allows the development of strategies to mitigate the risks related to variability (e.g., collect additional data, revise the mine plan, adapt or change the process strategy, or engineer flexibility into the system). Geometallurgy promotes sustainable development when all stages of extraction are performed in an optimal manner from a technical, environmental, and social perspective. To achieve these goals, development of innovative technologies and approaches along the entire mine value chain are being established. Geometallurgy has been shown to intensify collaboration among operational stakeholders, creating an environment for sharing orebody knowledge and improving data acquisition and interpretation, leading to the integration of such data and knowledge into mine planning and scheduling. These aspects create better business optimisation and utilisation of staff, and lead to operations that are more resilient to both technical and non-technical variability. Geometallurgy encompasses activities that utilise improved understanding of the properties of ore and waste, which impact positively or negatively on the value of the product, concentrate, or metal. Properties not only include those that impact on processing efficiency, but also those of materials which will impact on other actions such as blasting and waste management. Companies that embrace the geometallurgical approach will benefit from increased net present value and shareholder value.
\end{abstract}

Keywords: geometallurgy; orebody knowledge; mine value chain; variability; uncertainty; operational resilience

\section{Introduction}

Grade, mineralogy, and rock and mineral textures are variably distributed across metalliferous and other mineral deposits. This natural variability imparts a direct control on the metallurgical performance of ore feed across the Life Of Mine (LOM), where metallurgical performance is a function of mineralogy, grade, texture, and process conditions [1]. Where variability is not spatially quantified, 
then there is increased project risk and potential for revenue loss through reduced Net Present Value (NPV) [2-5].

Geometallurgy is an interdisciplinary activity that integrates geology, mining/geotechnical engineering, metallurgy, mineral economics, and geoenvironmental parameters to maximise project economic value, reduce risk, build resilience, and demonstrate good management of the resource [1,3,6-11]. Resilience relates to the capability of a mine operation to respond and recover from a disruptive event. In this context, orebody variability such as a period of sustained very-hard ore could reduce throughput and thus be disruptive. Geometallurgy allows this event to be forecast and managed during planning and may, for example, require a flexible process plant, engineered extra capacity, or a blending strategy.

Geometallurgy is an important strategy for any mining project, where the prime objective is to improve the profitability of mines through the use of spatial models of rock properties that have a significant impact on value $[4,12,13]$. While a key property is the grade of the component of interest, because it directly influences the revenue from saleable material, attention is increasingly being focused on other attributes. These non-grade variables may have a less direct but equal impact on value, either by reducing potential revenue (e.g., lowering recovery and deleterious elements) or increasing mining or treatment costs (e.g., comminution, grindability, throughput, and reagent use). Collectively, these variables can be described as being geometallurgical. There are three main areas of activity required to realise the value of geometallurgy $[1,3,6-11]$ :

- Acquisition of data through sampling and measurement.

- Building spatial models.

- Using these models to optimise value.

NPVs derived from spatial models have a significant impact on project risk reduction, through improved value resolution on a block by block basis. Development of a geometallurgical model requires access to samples that specify the key metallurgical processing properties. Beyond standard parameters collected by drilling, core logging, and geochemical analysis, additional characterisation is required. Focused and spatially distributed tests, i.e., small tests which characterise metallurgical properties and provide quantitative information on variability, need to be rapid and inexpensive [6,14-17]. A number of tests are available across comminution, recovery (e.g., leaching, gravity separation, and flotation), and geoenvironmental parameters.

The defining outputs from geometallurgy are 3D spatial (e.g., visualisation of drillholes, sample locations, domain boundaries, etc. (Figure 1)) and block (e.g., interpolated parameters (Figure 2)) models, where diverse attributes from core logging, mineralogical/textural determination, and small-scale tests serve to resolve grade, process parameters, and rock mass variability. The geometallurgical approach emphasises early Mine Value Chain (MVC) intervention, where geometallurgy can be broadly split into two key approaches related to project status: strategic and tactical (Table 1). The strategic approach focuses on the whole orebody and long-term LOM view, whereas tactical geometallurgy relates to the short- to medium-term operational view during mining [18]. 


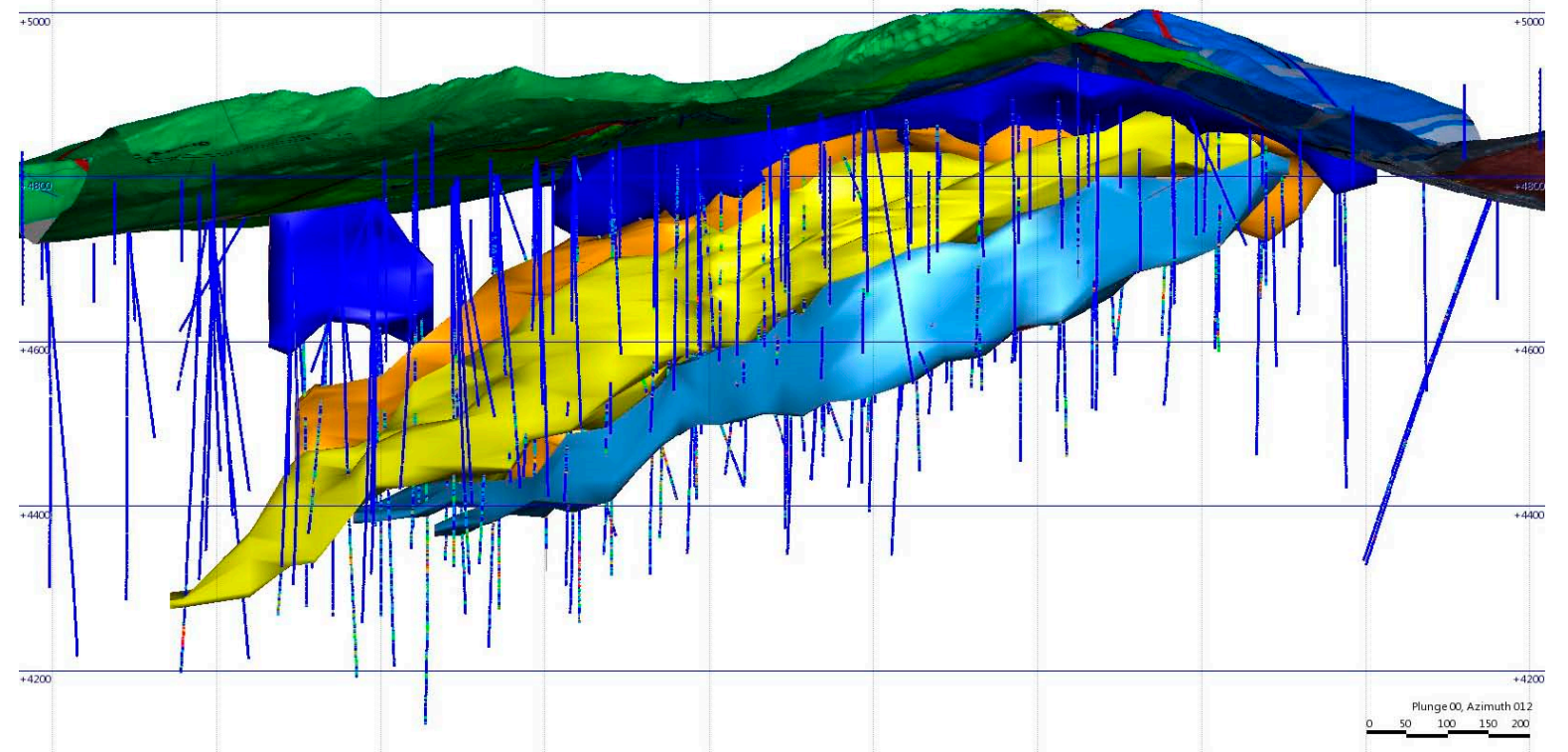

Figure 1. 3D model from the Canahuire deposit (Peru) displaying drillholes and generic domains based on lithology and alteration type. Blue: domain 400 (sub-economic silver mineralization). Orange: domain 300 (copper-gold breccia mineralization). Yellow: domains 200 (gold replacement mineralisation in limestone). Light blue: domain 100 (structurally-controlled gold in calcareous sandstone) (Reproduced with permission from Baumgartner et al. [19]).

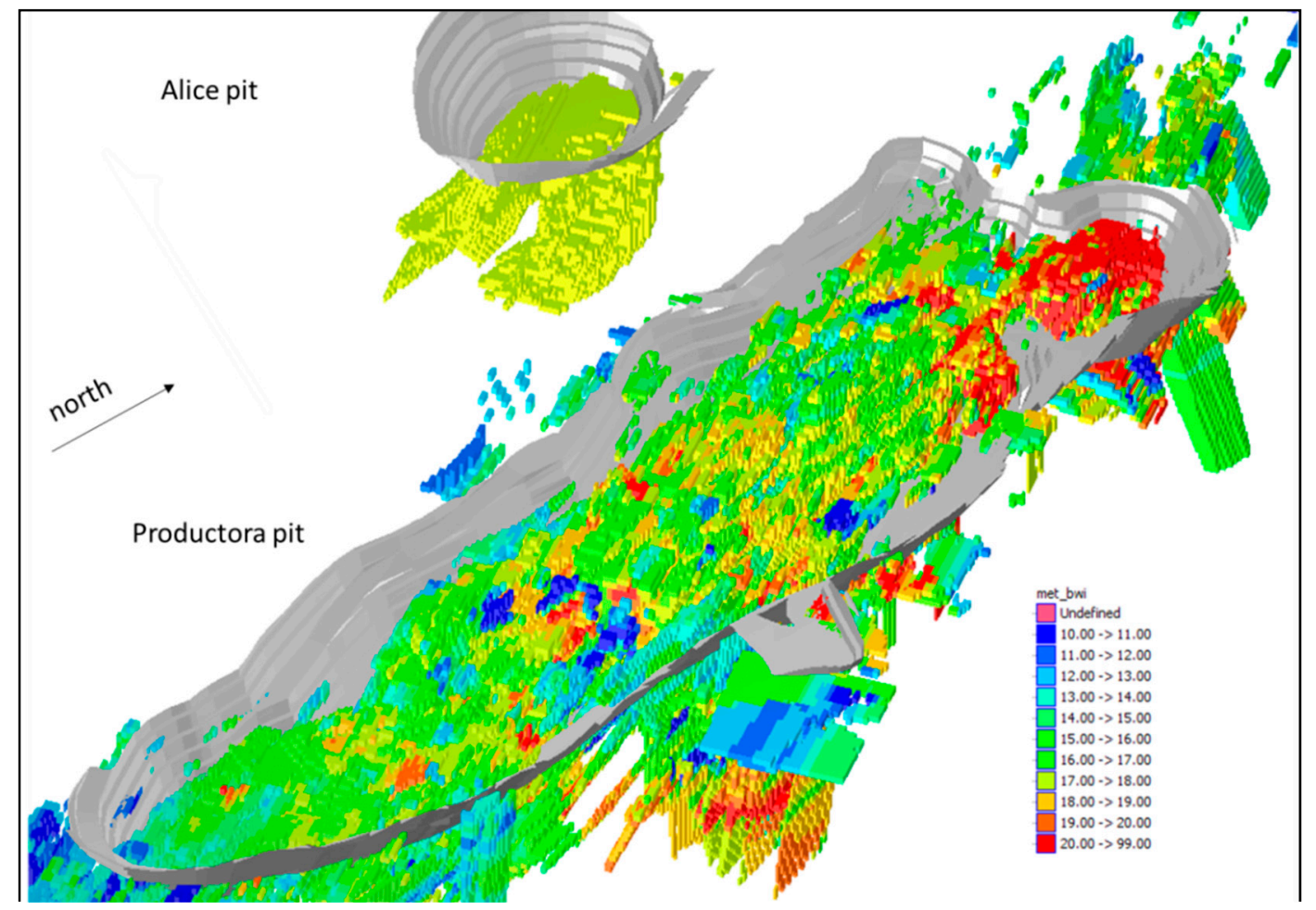

Figure 2. 3D block model of bond work index (BWi) values for the Productora and Alice Cu-Au-Mo pits (Chile). BWi for the main Productora deposit was estimated using aluminum and potassium values as proxies. The Productora pit is approximately $2.4 \mathrm{~km}$ long (Reproduced with permission from King and Macdonald [20]). 
Table 1. General mine value chain showing broad metallurgical-geometallurgical activities, inputs, and outputs.

\begin{tabular}{|c|c|c|c|c|c|}
\hline \multirow{2}{*}{ Stage } & \multicolumn{4}{|c|}{ Strategic Geometallurgy } & \multirow{2}{*}{$\begin{array}{c}\text { Tactical Geometallurgy } \\
\text { Mining }\end{array}$} \\
\hline & Exploration-Early Evaluation & Resource Definition Drilling & Reserve Definition Drilling & Feasibility & \\
\hline Study & Scoping (SS) & Pre-feasibility (PFS) & - & Feasibility (FS) & $\begin{array}{l}\text { Grade/ore control } \\
\text { (Expansion studies) }\end{array}$ \\
\hline Resources/Reserves & Inferred Mineral Resources & $\begin{array}{l}\text { Inferred and Indicated Mineral } \\
\text { Resources }\end{array}$ & $\begin{array}{l}\text { Mineral Resources and Ore } \\
\text { Reserves }\end{array}$ & $\begin{array}{l}\text { Mineral Resources and Ore } \\
\text { Reserves }\end{array}$ & $\begin{array}{l}\text { Mineral Resources and Ore } \\
\text { Reserves }\end{array}$ \\
\hline Key activity & $\begin{array}{l}\text { Develop orebody knowledge } \\
\text { Drilling and sampling }\end{array}$ & $\begin{array}{l}\text { Develop orebody knowledge } \\
\text { Drilling and sampling } \\
\text { Data analysis and modelling }\end{array}$ & $\begin{array}{l}\text { Develop orebody knowledge } \\
\text { Drilling and sampling } \\
\text { Data analysis and modelling }\end{array}$ & $\begin{array}{l}\text { Develop orebody knowledge } \\
\text { Drilling and sampling } \\
\text { Data analysis and modelling }\end{array}$ & $\begin{array}{c}\text { Develop orebody knowledge } \\
\text { Drilling and sampling } \\
\text { Data analysis and modelling }\end{array}$ \\
\hline Inputs & $\begin{array}{l}\text { Core logging } \\
\text { Develop proxy tests } \\
\text { Mineralogy } \\
\text { Geochemistry } \\
\text { Metallurgical testwork } \\
\text { Physical testing }\end{array}$ & $\begin{array}{l}\text { Core logging } \\
\text { Proxy tests } \\
\text { Mineralogy } \\
\text { Geochemistry } \\
\text { Metallurgical testwork } \\
\text { Physical testing }\end{array}$ & $\begin{array}{c}\text { Core logging } \\
\text { Proxy tests } \\
\text { Mineralogy } \\
\text { Geochemistry } \\
\text { Metallurgical testwork } \\
\text { Physical testing }\end{array}$ & $\begin{array}{c}\text { Core logging } \\
\text { Proxy tests } \\
\text { Mineralogy } \\
\text { Geochemistry } \\
\text { Metallurgical testwork, incl. } \\
\text { pilot or trial plant testing } \\
\text { Physical testing }\end{array}$ & $\begin{array}{c}\text { Core logging } \\
\text { Proxy tests } \\
\text { Mineralogy } \\
\text { Geochemistry } \\
\text { Metallurgical testwork } \\
\text { Physical testing }\end{array}$ \\
\hline Outputs & $\begin{array}{c}\text { Establish database } \\
\text { Preliminary characteristics of } \\
\text { mineralisation } \\
\text { Geological model; } \\
\text { Geoenvironmental }\end{array}$ & $\begin{array}{c}\text { Expanded database } \\
\text { Domains } \\
\text { Block model } \\
\text { Preliminary mine plan } \\
\text { Models } \\
\text { Preliminary process design } \\
\text { Geoenvironmental }\end{array}$ & $\begin{array}{c}\text { Expanded database across all } \\
\text { disciplines }\end{array}$ & $\begin{array}{c}\text { Expanded database } \\
\text { Domains } \\
\text { Block model } \\
\text { Mine plan } \\
\text { Models } \\
\text { Flow sheet } \\
\text { Scenario analysis } \\
\text { Economic analysis } \\
\text { Geoenvironmental } \\
\end{array}$ & $\begin{array}{c}\text { Expanded database } \\
\text { Domains } \\
\text { Block model } \\
\text { Mine planModels } \\
\text { Economic analysis } \\
\text { Forecasts } \\
\text { Reconciliation } \\
\text { Geoenvironmental }\end{array}$ \\
\hline Potential number of data ${ }^{1}$ & $1000 \mathrm{~s}$ & $1000-10,000 \mathrm{~s}$ & $+1000 \mathrm{~s}$ & $10,000-100,000 \mathrm{~s}$ & $100,000-1,000,000 \mathrm{~s}$ \\
\hline Resource uncertainty $^{2}$ & High & Moderate-High & Moderate & Low & Low \\
\hline Expected accuracy $^{3}$ & $\pm 50 \%$ & $\pm 25 \%$ & - & $\pm 15 \%$ & $\pm 10 \%$ \\
\hline
\end{tabular}


To meet the challenges of global resource needs, more complex orebodies are, and will, have to be mined. Their inherent challenges include:

- Declining ore grades.

- Geometrically and/or internally more involuted.

- Processing of more challenging ores with refractory and/or textural complexities.

- Deep-seated deposits with potentially high in-situ stress regimes.

Other challenges include:

- Increasing quantities of mine waste that need to be managed appropriately.

- Higher energy, water, and chemical costs.

- Stricter environmental/permitting and social conditions (the social licence to mine).

- Increasing demand for hard to process specialist/critical metals (e.g., rare earth elements and lithium).

- Commodity market volatility.

- Difficult funding environment.

As a result, efficiencies are required across:

- Orebody definition and revenue prediction.

- Mining methods that deliver a finer feed to the plant comminution circuit at lower cost.

- Optimised energy-efficient comminution circuits.

- Coarse particle beneficiation to reduce grinding.

- Beneficiation equipment and chemistry.

- Water and energy recovery.

- $\quad$ Leading practice social licence to operate.

The geometallurgical approach contributes to the above efficiencies and provides particular benefits in low-grade complex ores that may display a high variability (e.g., grade, and recovery and rock properties). Such ores have high risks which can manifest as low or negative profit margins if the operation is managed in a traditional way.

Some practitioners of geometallurgy still work in the context of 20 or more years ago, when the approach was dominated by process mineralogy and non-spatial (e.g., low-density of data not appropriate for block model construction) collection and analysis of data. In addition, current application can be part-siloed to geologists and mineral process engineers. This contribution provides a review of where geometallurgy is today and how it ultimately contributes to an optimised and resilient mine operation. It presents the development of geometallurgy to its current state and where it may go in the future.

\section{Overview of Geometallurgy}

\subsection{Variability and Uncertainty}

Two principle aspects of the geometallurgical approach are the quantification of variability and uncertainty. Their understatement may have negative impacts on mining, blending, and processing [3,12,21]. "Variability" reflects fluctuations in successive values (e.g., grade) either in space (spatial) or time (temporal), whereas uncertainty refers to any value for which there is incomplete knowledge (e.g., sparse sample data). Variability is a physical phenomenon that can be measured and analysed, whereas uncertainty is an aspect of knowledge [12].

Two types of uncertainty are identified: aleatory and epistemic uncertainty, or irreducible and reducible uncertainty [21]. Aleatory uncertainty relates to the inherent variability of a phenomenon and cannot be reduced, whereas epistemic uncertainty arises from incomplete knowledge of the phenomenon and can be reduced by more data. 
There may be significant epistemic uncertainty during early stages of the MVC when geological models are based upon sparse data (Table 1). In mining applications, the emphasis has largely been on aleatory uncertainty with acceptance that epistemic uncertainty is negligible [21]. Geostatistical simulation is widely used to quantify the effects of limited data on resource modelling (aleatory uncertainty), but the model (e.g., variogram and drilling pattern) is generally assumed to have negligible epistemic uncertainty.

There is additional uncertainty in extraction and processing an ore to produce a final product. A general approach to integrating this source of uncertainty is to quantify all sources of in-situ uncertainties and propagate them into simulated processes (e.g., blasting, loading, transport, and processing). There are two types of process uncertainty:

- Uncertainty associated with in situ variables which is propagated through processes applied to them. For example, the impact of grade uncertainty on mine design, which could be assessed by applying the same design process (e.g., optimal open-pit) to a range of simulated grade realisations.

- Uncertainty transferred to in situ variables by applying a process to them. An example is blasting a block of ground from which ore is selected.

The traditional approach to resource evaluation is based on kriging of grades and other parameters in a singular or deterministic 3D block model, where this approach fails to resolve variability or uncertainty. Optimised block models may be suitable for long-term planning, but are characterised by the smoothing of modelled variables. This effect potentially leads to the understatement of the impact of spatial variability at the selective mining unit (SMU) scale.

Uncertainty on the estimated attributes is only reducible by taking higher-quality and closer-spaced samples [22] and by improving geological understanding. Evaluation activities across the MVC collect increasingly more data through to the grade control programme, but there is irreducible residual uncertainty even in the closest economically-viable drilling pattern [12,21].

\subsection{Metallurgical versus Geometallurgical Approach}

The traditional metallurgical approach to plant design involves the testing of a number of composite samples that are reported to be representative of the ore body. Testwork is carried out to determine factors such as grindability, floatability, leach recovery, and/or other parameters. The testwork is often assumed to be appropriate and precise, and labelled as being "bankable". Subsequently, a process plant is constructed and commissioned and at some point, often within the first year of operation, found to be not performing to design [9]. The common reason for this relates to insufficient and unrepresentative samples and potentially inappropriate testwork. The traditional approach generally fails to account and cater for orebody variability $[8,9,23,24]$.

So-called "classical" geometallurgy is a collaboration between geology (mineralogy) and metallurgy (e.g., process mineralogy), with one discipline supplying the other with information and vice versa for a better understanding of the orebody and ore characteristics [9]. In essence, pushing more mineralogical knowledge into the plant design and/or process operation. However, little or any 3D spatial or block models result from this work and plant design is often based on apparently "average" ore-which in reality rarely exists.

\subsection{Modern Geometallurgy}

\subsubsection{Defining Modern Geometallurgy}

Modern geometallurgy can be defined as "an interdisciplinary activity that integrates geology, mining/geotechnical engineering, metallurgy, mineral economics, and geoenvironmental parameters to create spatially predictive 3D block models to maximise the economic value (e.g., NPV) of a mining project, reduce risk and build resilience". The ultimate question that a geometallurgical programme 
needs to be able to answer is: "how will block X perform when it is processed?" [18,24]. This leads to considerations of processing rate, metal or mineral recovery, product quality, and energy and reagent consumption during processing, which can be applied to develop an optimised mining sequence by considering production rates, costs, and operating stability [24]. The so-called modern geometallurgical approach emerged in the early 2000s, with its roots set in the 1980s [2,9].

Coward et al. [25] define key geometallurgical inputs as primary and response variables where:

- Primary variables are rock attributes that are independent of the measurement process employed.

- Response variables are attributes of rock (geology) that measure responses to processes.

A primary variable is intrinsic to the rock, for example grain size, metal grades, mineralogy, and other rock properties. Most primary variables are additive (e.g., grades per unit mass and mineral grades per unit volume) and can usually be averaged from both a sampling (compositing) and block modelling perspective. Response variables describe rock properties that are expressed as a response to a process or through energy application, for example throughput, grindability, metallurgical recovery, and intact rock strength. Due to the multivariate nature of these variables, the resulting distributions of the measured data can be complex (e.g., non-normal, negatively skewed, and bi-modal) and cannot easily be combined. Arithmetic averages generally do not produce a valid estimate of a number of samples or blocks [25]. The measurement of primary variables is key to determining response variables and building orebody knowledge.

Geometallurgy aims to understand metallurgical and mining (rock mass) parameter (e.g., response variables) variability based on information such as geochemistry, mineralogy, grade, and lithology (e.g., primary variables) obtained from spatially distributed samples or sample points. Spatially distributed small-scale tests can be used as proxies for grade, mineralogy, process parameter, and rock mass variability to allow for 3D block modelling (Figure 2) [6,14-17,26-28]. The ultimate aim is to predict the net revenue of each and every block in the model, and the likely variability within that block (e.g., grade, recovery, and hardness).

The outcomes of a geometallurgical programme will depend upon its objective, and ultimately the amount of data that feeds into the modelling process. Key issues relate to data quality and density, and the actual data collected. The number of process parameters is important, and may vary from a few (e.g., 1 or 2) to many (e.g., >10), where the density of that data will reflect the degree of variability resolution and for what purpose it can be used. Detailed data across five key parameters, for example, may provide high resolution variability models that are appropriate for a feasibility study to provide a full scenario-based analysis of NPV outcomes [12]. Conversely, low-density data across the same five key parameters may provide limited resolution variability models that are appropriate for a scoping study and provide a general forecast of NPV. In all models, the spatial distribution of the data impacts on the production timeframe of the model, where wide coverage may relate to whole-deposit LOM, and restricted coverage only a very limited period.

Geometallurgy is applicable to both metalliferous and industrial minerals projects, and across open pit and underground mines [11,22,29-32]. It has generally been applied to large deposits and open pit mines [33-36], though is equally applicable to small operations [22]. Geometallurgy can be split into two distinct, but complementary stages: strategic and tactical geometallurgy, which will be expanded upon later in this contribution.

\subsubsection{Value of Geometallurgy}

The principal value of geometallurgy ranges from improved understanding of orebody knowledge, through to more informed resource to reserve conversion and more adaptable mine plans, leading to an increase in the project NPV (Table 2). 
Table 2. Published examples of geometallurgy adding value.

\begin{tabular}{|c|c|c|c|}
\hline Example & Overview & Value & Reference \\
\hline $\begin{array}{l}\text { San Antonio Au, South } \\
\text { America }\end{array}$ & $\begin{array}{l}\text { PFS and operational } \\
\text { (underground) execution lead to } \\
\text { smaller high-grade selective } \\
\text { underground mine with smaller } \\
\text { more sustainable footprint }\end{array}$ & $\begin{array}{l}\text { Increased NPV by US\$15M } \\
\text { Reduced CAPEX } \\
\text { Revised mine plan } \\
\text { Improved resource-reserve } \\
\text { conversion }\end{array}$ & Dominy et al. [22] \\
\hline Ruashi Cu-Co, DRC & $\begin{array}{l}\text { Operational (open pit) } \\
\text { application lead to model of } \\
\text { throughput, acid consumption, } \\
\text { and recovery. This drove an } \\
\text { improve stockpile and plant } \\
\text { feed strategy }\end{array}$ & Increase NPV by US $\$ 127 \mathrm{M}$ & $\begin{array}{l}\text { Macfarlane and } \\
\text { Williams [32] }\end{array}$ \\
\hline $\begin{array}{l}\text { Olympic Dam Cu-Au, } \\
\text { Australia }\end{array}$ & $\begin{array}{l}\text { Operational (underground) } \\
\text { execution across the short, } \\
\text { medium, and long term mine } \\
\text { plan }\end{array}$ & $\begin{array}{l}\text { Reduced technical risk across } \\
\text { the current operation and future } \\
\text { expansions due to variable ore } \\
\text { properties }\end{array}$ & $\begin{array}{l}\text { Ehrig [1]; Liebezeit } \\
\text { et al. [35] }\end{array}$ \\
\hline $\begin{array}{l}\text { Cripple Creek and Victor } \\
\mathrm{Au} \text {, USA }\end{array}$ & $\begin{array}{l}\text { Operational execution across the } \\
\text { short, medium, and long term } \\
\text { mine plan }\end{array}$ & $\begin{array}{l}\text { Optimisation of different ore } \\
\text { types to two separate process } \\
\text { plants }\end{array}$ & $\begin{array}{l}\text { Leichliter and } \\
\text { Larson [34] }\end{array}$ \\
\hline $\begin{array}{l}\text { Productora } \mathrm{Cu}-\mathrm{Mo}-\mathrm{Au} \text {, } \\
\text { Chile }\end{array}$ & $\begin{array}{l}\text { PFS stage execution to optimise } \\
\text { mine and processing (flotation } \\
\text { and heap leach) schedules }\end{array}$ & $\begin{array}{l}\text { US } \$ 25 \mathrm{M} \text { increase in NPV } \\
5 \% \text { reduction in CAPEX }\end{array}$ & $\begin{array}{l}\text { King and } \\
\text { Macdonald [20] }\end{array}$ \\
\hline Degrussa Cu-Au, Australia & $\begin{array}{l}\text { Operational execution to } \\
\text { quantify key metallurgical } \\
\text { variability }\end{array}$ & $\begin{array}{l}\text { Forecasting to allow improved } \\
\text { blend strategies and plant } \\
\text { performance }\end{array}$ & Butler at al. [30] \\
\hline $\begin{array}{l}\text { Orapa kimberlite } \\
\text { (diamond), Botswana }\end{array}$ & $\begin{array}{l}\text { Operational (open cut) } \\
\text { application to model kimberlite } \\
\text { comminution properties }\end{array}$ & $\begin{array}{l}\text { Feed optimisation to two } \\
\text { process plants } \\
\text { Improved NPV }\end{array}$ & $\begin{array}{l}\text { Lechuti-Tlhalerwa, } \\
\text { Gilika and } \\
\text { Field [36] }\end{array}$ \\
\hline Canahuire $\mathrm{Cu}-\mathrm{Au}-\mathrm{Ag}$, Peru & $\begin{array}{l}\text { Evaluation (PFS) stage execution } \\
\text { in complex orebody }\end{array}$ & $\begin{array}{l}\text { Preliminary definition of } \\
\text { domains and potential } \\
\text { metallurgical recovery } \\
\text { variability, ARD potential, and } \\
\text { penalty elements }\end{array}$ & $\begin{array}{l}\text { Baumgartner } \\
\text { et al. }[19,37]\end{array}$ \\
\hline La Colosa Au, Colombia & $\begin{array}{l}\text { PFS stage execution in complex } \\
\text { orebody }\end{array}$ & $\begin{array}{l}\text { Definition of comminution } \\
\text { domains }\end{array}$ & Montoya et al. [33] \\
\hline
\end{tabular}

From a management and corporate perspective, an effective geometallurgy programme will have resulted from the close collaboration of the project/mine technical teams across all disciplines. Beyond any technical and NPV value-add afforded by geometallurgy, multi-disciplinary working practices will also yield non-tangible dividends.

Mineral Resource to Ore Reserve conversion is generally within the range of $25-50 \%$, depending on deposit type and commodity. The application of geometallurgy generally has the favourable consequence of increasing this conversion through the evaluation of alternate mining and processing scenarios. In the case study reported by Dominy et al., the application of geometallurgy increased the resource to reserve conversion factor from $50 \%$ to $70 \%$ based on a revised mining and process strategy [22]

\subsubsection{Comparing and Communicating Geometallurgical Programmes}

A downside to modern geometallurgy is that there are a number of definitions and perspectives on the topic [9]. Some still consider that classical geometallurgy is appropriate in the modern world. The clear mantra is that of collaboration between the relevant disciplines. This requires a common understanding of geometallurgical programme goals to be obtained, which requires open and consistent communication. Jackson, McFarlane, and Olson Hoal propose a multi-dimensional construct to assist in the communication of programme context and purpose [7]. 
The geometallurgical framework (Figures 3-5) comprises six dimensions-parameters, resolution, variability, timeframe, application, and project stage (modified from Jackson, McFarlane and Olson Hoal) [7]:

- Parameters: refers to the process parameters being modelled in the programme. These may range from rock mass (RQD and RMR), though to recovery (gravity, leach and flotation), comminution (BWi, SMC and $\mathrm{Ai}$ ), and/or geoenvironmental parameters (NAF and PAF).

- Resolution: refers to the level of detail in a programme that may range from high to low. In some cases, a detailed knowledge of the parameter (e.g., flotation) and its components (e.g., mineralogy) are needed, whereas in others a relative indication is required. It links to data density, where more data leads to better resolution (e.g., lower uncertainty).

- Variability: A generic domain is a 3D volume based on a geological variable(s) such as lithology or alteration, which may or may not be statistically homogenous for the response(s) in question. A process specific domain is a $3 \mathrm{D}$ volume where the response variable under consideration comes from a statistically homogenous population. Within a given domain, there will be a range of variability knowledge from limited to high, where knowledge extends to many or all drill holes within the domains.

- Timeframe: refers to the volume of mineralisation in question as nominal production periods. The shortest time period is limited-essentially a snapshot sampling campaign of a section of the deposit or across the deposit with a broad life of mine view. Other periods are project dependent as short-term (e.g., 6 months), medium-term (e.g., 6-18 months), and long-term (e.g., >18 months or more) production periods.

- Application: relates to how the geometallurgical information is used and ranges from proactive (e.g., developing the programme) through to enough data to provide key parameter forecasts on a given timeframe, and ultimately full scenario-based assessment.

- Project stage: at what stage of the MVC the project sits.

The geometallurgical framework provides a useful reference and comparison tool. In Figure 3, the two broad end members of geometallurgical study are presented. Orange blocks indicate an early stage strategic programme, where only a few parameters are modelled with low resolution and for a limited part of the mineralisation. In the tactical case, the red blocks indicate an advanced tactical programme, where a number of parameters are modelled with high resolution in defined domains.

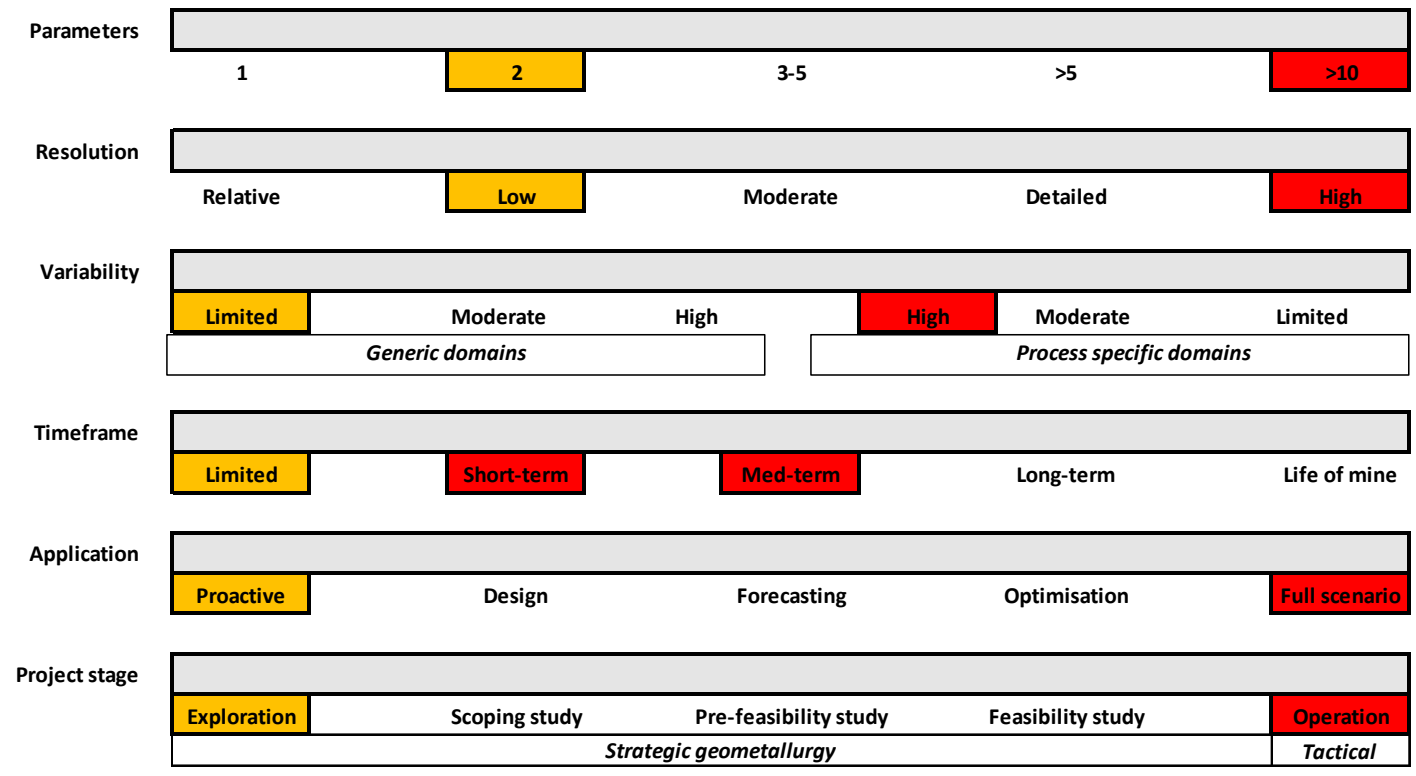

Figure 3. Geometallurgical framework (modified from Jackson, McFarlane and Olson Hoal [7]). 
Figures 4 and 5 show two projects ranging from an operating mine to advanced exploration. The San Antonio project (Figure 4) models six parameters (e.g., grade, GRG recovery, flotation recovery, sulphide content, density, and hardness) to provide a detailed model of variability in generic domains to support the medium-term mine plan (6-12 months) and including the short-term mine plan (3-6 months). The programme allows optimisation of both mining and processing in an active mine. The Canahuire project (Figure 5) uses eight parameters (e.g., penalty elements, ARD indices, and grade) to provide a moderately detailed model of variability in generic domains to support a broad whole deposit plan. The programme supports design at the advanced exploration stage towards a scoping study.

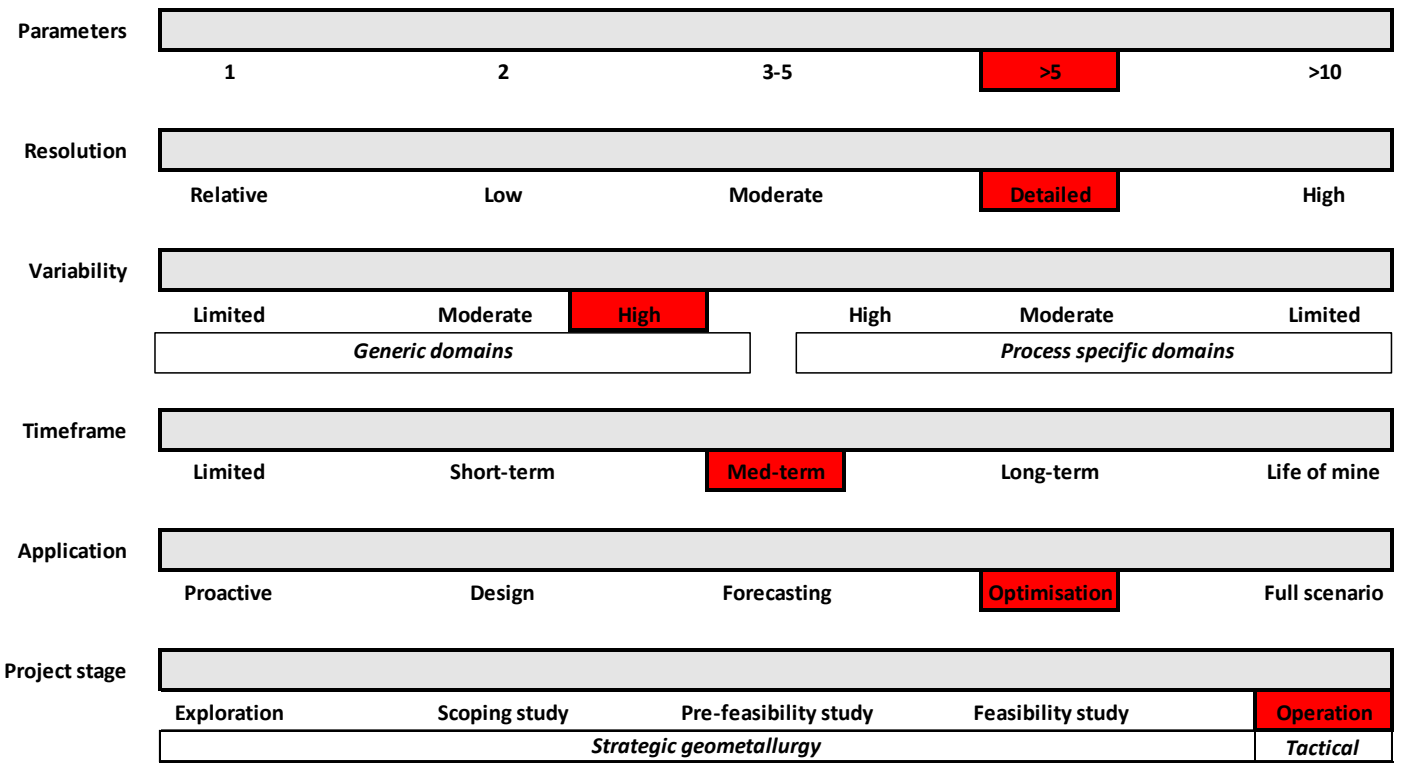

Figure 4. Geometallurgical framework applied to the San Antonio gold mine [22].

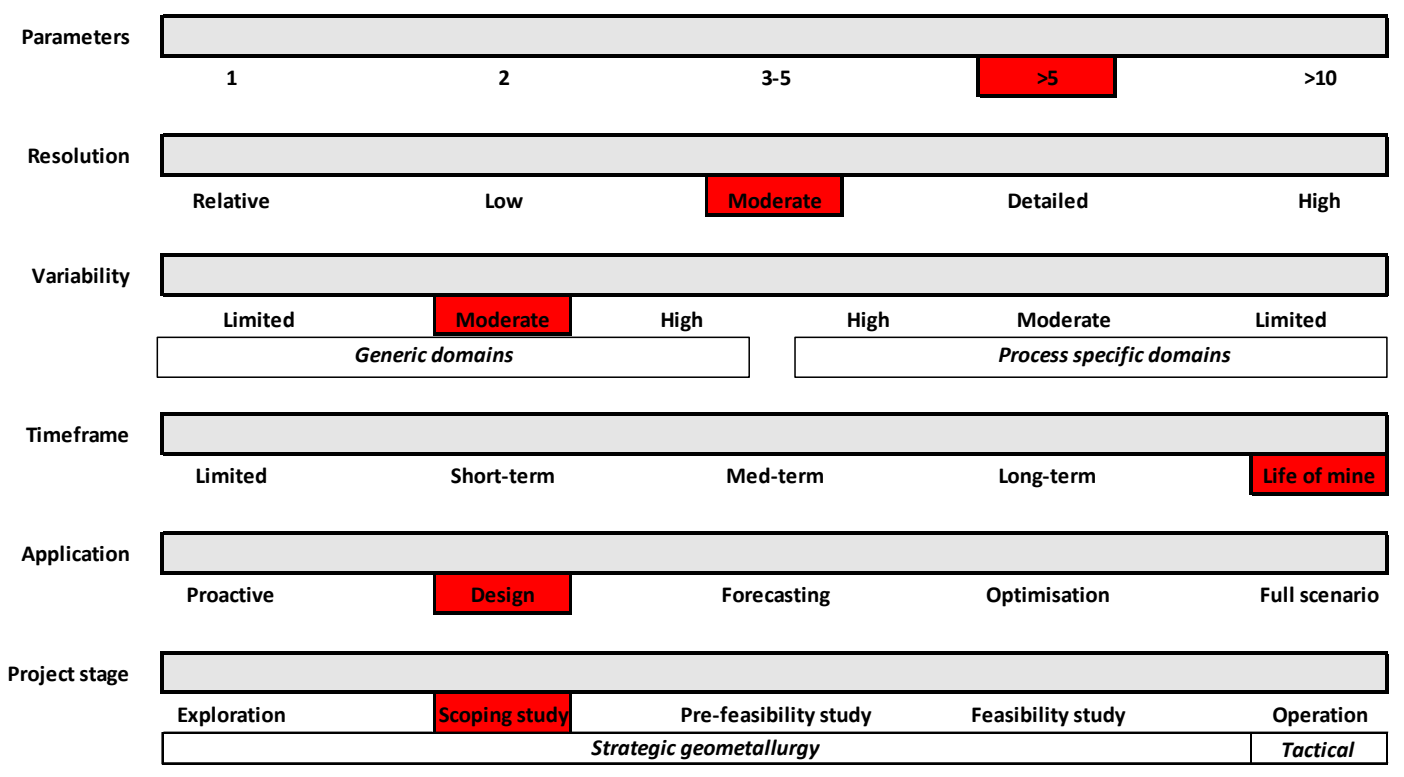

Figure 5. Geometallurgical framework applied to the Canahuire gold-copper-silver project [19,37].

\subsubsection{Building Orebody Knowledge}

Orebody knowledge comprises an understanding of orebody characteristics relevant to geological, mining, processing, and geoenvironmental issues (e.g., grade, mineralogy, contaminants, alteration patterns, ore hardness, and geotechnical properties). These characteristics will display variability and 
uncertainty based on the level of data density. Limitations in their interpretation and modelling will increase technical and business risks. Poor orebody knowledge leads to sub-optimal mine and/or plant design, lower than expected operational performance, and loss of reserves. Orebody knowledge must be developed in a coherent fashion and to a level of detail that minimises risk and allows the identification of value-maximising solutions (Figures 3-5). High quality core, data readings, samples, sub-samples, and subsequent testwork are required to support estimates or studies to be reported within the framework of any international code.

The basis of developing orebody knowledge is that of drilling, sampling, and measurement collection. The integration of core logging (e.g., lithology, alteration, EQUOtip, and RQD), mineralogical (e.g., QXRD/PXRD), geochemical (e.g., PXRF/LIBS and ICP-AES/MS), physical testing (e.g., JKRBT, SPI, BWi, and $\mathrm{A}^{*} \mathrm{~b}$ ), metallurgical recovery (e.g., GRG, JKFI, and leach), and geoenvironmental (e.g., NAF and PAF) data leads to the prediction of key parameters through correlation and block modelling (Figure 2).

Traditional metallurgical testwork requires a significant amount of sample material (often 10-200 kg; Dominy et al. [23]) and is time consuming and expensive to complete. They typically yield hundreds of results at the Feasibility Study stage, whereas a geometallurgical programme will result in thousands of spatially distributed data points that can be used to inform a block model $[8,38]$.

Metallurgical testwork is carried out to determine factors such as grindability, floatability, leach recovery, and/or other parameters, and is critical for plant design. Subsequently, a process plant is constructed and commissioned and at some point, often within the first year of operation, may be found not to be performing to design. The common reason for this relates to insufficient and unrepresentative samples and potentially inappropriate testwork [2,22-24]. Additionally, metallurgical variability is not resolved due to: (a) sample compositing, and/or (b) not enough spatially distributed samples. In essence, testwork results are often precise, but with uncertain representativity [23]. McCarthy [39] identified a number of common flaws in feasibility studies which lead to operational underperformance for which $15 \%$ related to metallurgical sampling and testwork, and 12\% process plant design issues.

Traditional metallurgical samples are not appropriate for geometallurgical studies, given that numerous spatially distributed samples or proxies are required to inform a block model(s). Proxies will, however, be validated against traditional testwork results, therefore traditional testwork samples are an inherent part of geometallurgy. Table 3 presents an example protocol for the determination of key primary and response variable parameters from drill core [40]. Other case specific examples of protocols are provided in Carrasco, Keeney and Walters, Ehrig and Pitard, and Dominy et al. [22,41,42].

Table 3. Example geometallurgical test programme for a porphyry copper-gold mineralisation based on half HQ core (modified from Keeney [40]).

\begin{tabular}{|c|c|c|c|c|}
\hline Stage & Activity & Test work & Outcome & Mass used \\
\hline 1 & $\begin{array}{l}\text { Continuous core } \\
\text { logging }\end{array}$ & $\begin{array}{c}\text { Logging and photography } \\
\text { GEOTEK logger } \\
\text { HyLogger } \\
\text { EQUOtip }\end{array}$ & Intact core characteristics & $\begin{array}{l}\text { Half HQ core in } \\
2 \mathrm{~m} \text { lengths } \\
\text { (approx. } 8.5 \mathrm{~kg} \text { ) }\end{array}$ \\
\hline 2 & Texture & $\begin{array}{c}\text { GEOTEK camera } \\
\text { AMA }\end{array}$ & $\begin{array}{c}\text { Core image } \\
\text { Polished tablet image }\end{array}$ & $0.5 \mathrm{~kg}$ \\
\hline 3 & Comminution & $\begin{array}{c}\text { Crushing } \\
\text { Rotary breakage device }\end{array}$ & $\begin{array}{l}A^{*} b \\
J K C I\end{array}$ & $2 \mathrm{~kg}$ \\
\hline 4 & Analysis & $\begin{array}{c}\text { Assay } \\
\text { Geochemical analysis }\end{array}$ & $\begin{array}{c}\text { Assay for economic } \\
\text { metal(s) } \\
\text { Multi-element analysis }\end{array}$ & $\begin{array}{l}\text { Approx. } 6 \mathrm{~kg} \\
\text { (sub-sampled for } \\
\text { stages } 5-7 \text { ) }\end{array}$ \\
\hline 5 & Mineralogy & AMA & $\begin{array}{l}\text { AMA on screened } \\
\text { fractions }\end{array}$ & $1-2 \mathrm{~kg}$ \\
\hline 6 & Grinding & Batch grind & $\begin{array}{l}\text { Batch grind on four size } \\
\text { fractions }\end{array}$ & $1-2 \mathrm{~kg}$ \\
\hline 7 & Flotation & JK flotation index & $\begin{array}{c}\text { JKFI } \\
\text { AMA and assays on } \\
\text { selected products }\end{array}$ & $1-2 \mathrm{~kg}$ \\
\hline
\end{tabular}


Data management is a significant consideration for any geometallurgical programme [43]. While geologists are experienced at dealing with thousands of samples and their associated assays, metallurgists have traditionally carried out relatively few tests and consequently often manage data in spreadsheets. Data can range from, for example, $>1.6 \mathrm{M}$ geochemical assays from $2200 \mathrm{~km}$ of drill core at Olympic Dam, Australia [42,43], to 4500 assays from $16 \mathrm{~km}$ of drill core at San Antonio [22]. Geometallurgy presents significant data management challenges as a result of the large volume of data generated. Considerations for any data management system include storage space, data integrity, accessibility, sample provenance, maintenance and ease of use, integration with data providers, and the ability to modify the system to adapt to changing requirements [43]. Based on experience of the authors, the best database is a bespoke one that is designed for the specific project/mine in question. This should be fully portable to whatever software is applied for modelling, estimation, and mine planning.

\section{Stages and Strategies for Modern Geometallurgy}

\subsection{Introduction}

The geometallurgical approach emphasises early stage intervention and progression across the MVC (Table 1) $[1,19,20,37]$. The project/tactical approach focuses on the whole orebody and long-term LOM view, whereas operational/tactical geometallurgy relates to the short- to medium-term view during mining. Operational geometallurgy adds to, and draws from, the project database $[18,35,44]$, and is focused on defining feed variability for forecasting and blending purposes. The strategic and tactical geometallurgy definitions of McKay et al. [18] are used throughout this contribution.

\subsection{Strategic Geometallurgy}

Strategic geometallurgy delivers value to a Mineral Resource during the development, planning, operation, and closure phases [18]. The model is created in stages, commencing during exploration and project evaluation (studies) phases with the first set of drilling. It seeks to meet the needs of production, and is not complete until mining, remediation, and other activities requiring information on the spatial variability of relevant parameters are completed. The global strategic geometallurgical model is also strengthened by local information acquired in a tactical geometallurgy programme (Table 4).

Table 4. Framework for the development and maintenance of a strategic geometallurgical programme (modified from McKay et al. [18]).

\begin{tabular}{|c|c|c|c|}
\hline Stage & Activity & Actions & Outputs \\
\hline 1 & Drilling & $\begin{array}{c}\text { Core logging } \\
\text { Core imaging } \\
\text { Down-the-hole measurements }\end{array}$ & $\begin{array}{l}\text { Rock types/alteration } \\
\text { Geotechnical } \\
\text { Geophysical }\end{array}$ \\
\hline 2 & Testwork & $\begin{array}{c}\text { Analysis } \\
\text { Mineralogy } \\
\text { Physical testwork } \\
\text { Recovery testwork }\end{array}$ & $\begin{array}{l}\text { Assays/geochemistry } \\
\text { Metal/mineral deportment } \\
\text { Comminution/hardness } \\
\text { Flotation, leach, gravity }\end{array}$ \\
\hline 3 & Data management & Database & Validated database \\
\hline 4 & Modelling & $\begin{array}{c}\text { Domain analysis } \\
\text { Geological modelling } \\
\text { Geostatistical modelling }\end{array}$ & 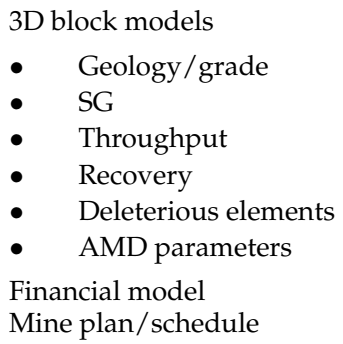 \\
\hline
\end{tabular}


The strategic geometallurgical block model is a representation of a 3D orebody that contains information on a broad range of characteristics, including: grade(s), lithology, geological contacts, ore, gangue and deleterious minerals, geotechnical structures, rock texture, hardness, mineral recovery, and environmental parameters. The block model provides the information base for developing an optimised mine model, metal production schedule, and cash-flows over the LOM and medium-term time-frame (e.g., 5 year).

The most critical part of constructing a geometallurgical model is the input drilling, sampling, testwork, and assaying. The core, rock chips, and fine or coarse splits produced are the most important single repository of knowledge that exists for the orebody. Drill core is not only used for obtaining geological and assay information but provides data to populate the block model. Geotechnical parameters (e.g., fracture frequency and RQD) can be modelled as an indicator of ore hardness and potentially correlated with blastability, crushing, and grinding hardness. Geophysical data can be obtained either down-hole or from core to provide indicative measurements on rock type and qualities.

Numerous tests can be performed to measure hardness, flotation recovery, leach recovery, and other parameters given enough samples. These are relatively expensive and use large quantities of core and require commercial laboratory facilities. Testing must be sufficient to understand the variability of the ore. Rock types that have high degrees of variability should receive enough testing until its impact is resolved. Processing additivity should be established for ores that will be blended or stockpiled together. The testing should also aim to assess the often complex relationship between the predictive bench-scale test results and actual industrial plant behavior (or scale-up).

Data acquired during drilling, logging, and testing must be stored in a relational database. Successful data management that supports and enables both strategic and tactical geometallurgical initiatives need to provide real-time access to all data. Data management increasingly relies on new technologies and automated/semi-automated workflows to capture data objectively (e.g., hyperspectral core scanning systems), use machine-learning algorithms for interpretation, and to construct 3D models with implicit modelling software. The key objective of strategic geometallurgy is to create iterative models to guide mining and processing decisions in the context of metal production and cash flows.

\subsection{Tactical Geometallurgy}

The multiple data streams used for tactical geometallurgy include the grade and metallurgical response information from both the block model and recent ore control drilling, in additional to the short-term mine plan, pit conditions and access, ore availability, equipment availability, stockpile space, and plant performance [18]. Tactical geometallurgy can be viewed as the (near) real-time application of the strategic model to enhance the mining process (Table 5).

The processing plant takes parcels (e.g., blocks) of ore and turns them into value, which requires the feed to conform to specific characteristics of grade (e.g., measured by drilling and testing), size distribution (e.g., created by drilling, blasting and crushing), and metallurgical performance characteristics (e.g., measured by drilling and testing). This process is better described as ore control as opposed to the more traditional grade control. Tactical geometallurgy aims to produce predictable ore based on the use of data inputs from long-term (strategic) and short-term (ore control) models.

The tactical geometallurgical block model is created to support the short-term mine plan, where model implementation is dependent upon mine type and scale (e.g., large open pit versus small underground). The timeframe between tactical modelling and mining is likely to be on the scale of 2-6 months, depending on the frequency of ore control. Where RC drilling is used for open pit ore control, the timeframe is likely to be on the scale of months. A tactical model is based upon data both from the strategic model and ore control drilling.

The chips produced from ore control drill and blast drilling (assuming open pit mining) can provide a source of pre-crushed ore intervals which can be used for variability testing. Important considerations for the effective use of drill chips for testing are the size distribution of the chips 
produced and the quality of the ore control sampling and splitting. RC drills can be fitted with modules to collect chip samples, where they provide sufficient mass for metallurgical testwork, an advantage over more limited and widely-spaced diamond drill cores. Ore control drill chips may be used for chemical analysis (e.g., metals, lithogeochemical, and traces), mineralogical analysis, grinding hardness, flotation recovery, and rheological and geoenvironmental information. Inherent problems of the representative sampling of RC drill chips relate to non-optimal sub-sampling (e.g., splitting) and fines loss (e.g., FSE, DE, EE, and WE; see Table 6). Sampling protocols require appropriate optimisation through material characterisation and TOS application [22,23]. The utilisation of state-of-the-art sampling units may be required (e.g., the Progradex ${ }^{\mathrm{TM}}$ system) [45].

Table 5. Planning framework for development and maintenance of tactical geometallurgical programme (modified from McKay et al. [18]).

\begin{tabular}{|c|c|c|c|}
\hline Stage & Activity & Actions & Outputs \\
\hline 1 & $\begin{array}{c}\text { Drilling (Open pit: RC, core, } \\
\text { and/or blasthole) } \\
\text { (Underground: RC, core, } \\
\text { blasthole, or faces) }\end{array}$ & $\begin{array}{l}\text { Measure-while-drilling } \\
\text { Core/chip logging }\end{array}$ & $\begin{array}{c}\text { Rock types/alteration } \\
\text { Geotechnical } \\
\text { Geophysical }\end{array}$ \\
\hline 2 & Testwork & $\begin{array}{c}\text { Analysis } \\
\text { Mineralogy } \\
\text { Physical testwork } \\
\text { Recovery testwork }\end{array}$ & $\begin{array}{l}\text { Assays/geochemistry } \\
\text { Metal/mineral deportment } \\
\text { Comminution/hardness } \\
\text { Flotation, leach, gravity }\end{array}$ \\
\hline 3 & Modelling & $\begin{array}{c}\text { Domain analysis } \\
\text { Geological modelling } \\
\text { Geostatistical modelling }\end{array}$ & $\begin{array}{l}\text { Update strategic block model } \\
\text { Ore control block model } \\
\text { Integrated pit or underground } \\
\text { mappingBlock allocation }\end{array}$ \\
\hline 4 & Mining & $\begin{array}{l}\text { Mine design/planning } \\
\text { Reconciliation }\end{array}$ & $\begin{array}{l}\text { Blast design (stope or bench) } \\
\text { Blending strategy } \\
\text { Stockpile management } \\
\text { Validated model }\end{array}$ \\
\hline 5 & Processing & $\begin{array}{l}\text { Plant feed optimisation } \\
\text { Reconciliation }\end{array}$ & $\begin{array}{l}\text { Optimised plant } \\
\text { Validated model }\end{array}$ \\
\hline
\end{tabular}

In parallel, information from drilling can be correlated with hardness measurements and whole rock analysis, RQD, or point load testing (e.g., EQUOtip) so that drill-based predictions are calibrated. In the underground environment, diamond core samples and face samples will have to be optimised to provide the data $[35,42,46]$.

While the strategic model provides the initial framework of geology, grade, and processing performance information, additional data in the tactical programme is modelled to define the value of each block. Geometallurgy does not end with the delivery of ore to the plant. Ore feed passes to the crushers, mills, and concentrator or leach pad, and ultimately smelters and refineries, and on to waste piles and into tailings dams. Each unit process has quality specifications that will impact upon the overall value of each ore block.

\subsection{Geoenvironmental Aspects of Geometallurgy}

Orebodies are non-renewable resources whose extraction may produce significant quantities of waste. It is estimated that globally, 20-25 Gt of waste rock and $14 \mathrm{Bt}$ of mine tailings are produced by the mining industry $[47,48]$. Appreciably, the quantity of waste produced far exceeds the tonnage of metal recovered, suggesting that what we are really mining is not ore, but waste. Therefore, determining the waste properties must be given appropriate attention with associated costs built into the mine budget if mine closure is to be appropriately executed and signed off by the regulatory authorities. If inadequately determined and managed, mine waste can pose several geoenvironmental risks. For example, the generation of mineral dusts (i.e., from dry-stack tailings surfaces) potentially poses human health risks to employees and communities in proximity to mining activities [49]. However, the 
most significant risk associated with mine waste is the formation of acid and metalliferous drainage (AMD) generated by the oxidation of sulphides, commonly present in these wastes [50]. The cost of managing the AMD is considerable with recent estimates stating that the rehabilitation of one hectare is at least AU\$100,000 [47,48]. To minimise long-term environmental liabilities associated with managing these impacts (potentially affecting project NPV), better identification of the geoenvironmental risks posed at the earliest LOM stages is required.

The key to improving the management of AMD is to examine and define the mineralogical properties of waste. Traditionally, a select number of representative samples are collected and subjected to a range of static geochemical tests $[50,51]$ to determine whether they are PAF or NAF, therefore enabling the planning of waste handling schedules and the final landforms. However, by not determining the mineralogical properties, only an approximation of the mineral reactions that may occur in the final waste repository or landform can be afforded. Further, if waste materials are actually of value to the operation (i.e., if clays are present which could be used for waste capping or neutralising materials e.g., Savage River mine, Tasmania [52]) then by examining mineralogy, these beneficial properties can be revealed. Further, additional commodities could be extracted from the waste if, for example, the mineral chemistry of mine tailings are examined during metallurgical testwork, and if discovered, its recovery could be built into the metallurgical flowsheet. New mineralogical tools are available to enable the definition of these waste properties [53]. Their application at the earliest LOM stages will enable effective mine closure planning as remediation and rehabilitation strategies can be developed based on the deposits properties and realistically costed, with ample opportunities for community feedback and regulatory consultations, thereby ensuring the social licence to operate is granted. During operational phases of the LOM, mineralogical investigations supported by static chemical testing should be performed as part of 'waste control' to check placement against plan. At mine-closure, regular monitoring should be performed to evaluate the success of rehabilitation and if necessary, the strategy should be amended if pollutant linkage chains are identified.

\section{Key Dimensions of Geometallurgy}

\subsection{Introduction}

Geometallurgy includes many disciplines and sub-disciplines applied across the MVC. Beyond consideration of traditional geological, mining, and minerals engineering topics integrated into project studies and mine plans (Table 1), other areas have become important, particularly geoenvironmental parameters such as AMD potential and contents of environmentally deleterious elements. These are now being integrated into 3D models to guide the mining operation and requirements for blending and/or treatment.

The mining industry is expanding to include many non-typical disciplines such as data analytics/data science, artificial intelligence/machine learning, and automation/robotics, as well as the introduction of innovative technologies. All of these will have a positive impact onto geometallurgical studies. However, traditional activities are important and should not be lost in the rush for new technology application. This section provides an overview of selected key dimensions of geometallurgy that warrant discussion - it is not intended to be an all-encompassing coverage. It repeats and develops upon some topics previously discussed in this review.

\subsection{Sampling}

\subsubsection{Introduction}

Sampling is a basic component during all stages of the MVC and if done optimally, is key to reducing uncertainty $[54,55]$. It includes the sampling of in-situ material (e.g., drilling, linear, and bulk sampling $[22,23,46,55])$ and broken rock (e.g., stockpile, belt, and percussion drill sampling $[22,23,46,55])$ for geological (e.g., resource definition), metallurgical (e.g., for plant design), 
geometallurgical (e.g., variability and spatially distributed samples), and geoenvironmental (e.g., NAF and PAF) purposes [51]. Despite its obvious importance, sampling is frequently considered a second-class citizen and does not receive the rigorous treatment that it requires $[23,24,46,55,56]$. It is highly relevant to any geometallurgical programme, since grade, metallurgical, and geoenvironmental samples will still need to be collected and tested/assayed.

The quality and type of samples collected are as important as the testwork and assaying applied. The key characteristic of any set of samples is that they represent a given domain and quantify its variability. There are those who think that stating a sample(s) is representative makes it representative without justification. There is a need to consider both: (1) in situ, and (2) testwork sub-sample representativity [23,42,57]. Early ore and waste characterisation and domain definition are required, so that sampling, testwork, and assaying protocols can be designed to suit the style of mineralisation in question.

\subsubsection{Theory of Sampling and Sampling Errors}

The Theory of Sampling (TOS) provides an insight into the causes and magnitude of errors that may occur during the sampling of particulate materials (e.g., broken rock) and is applicable to geometallurgical sampling in its widest sense [23,51,54,55].

Sampling error is defined in the context of TOS, where actions may lead to uncertainty and create an overall measurement error [54,55]. TOS attempts to break down this error into a series of contributions along the sampling value chain (e.g., the planning to assay-measurement process: Table 6).

Table 6. Sampling value chain.

\begin{tabular}{|c|c|c|c|c|c|c|}
\hline Location & & Site/Field & & & Laboratory & \\
\hline \multirow{2}{*}{ Stage } & Planning & Collection & Transport & Preparation & Testwork & Assaying \\
\hline & 1 & 2 & 3 & 4 & 5 & 6 \\
\hline Activity & Scope Develop Execute & $\begin{array}{l}\text { Observe Collect } \\
\text { Bag and tag } \\
\text { QAQC } \\
\text { Integrity/security } \\
\text { Chain of } \\
\text { custody }\end{array}$ & $\begin{array}{l}\text { Integrity/security } \\
\text { Chain of } \\
\text { custody }\end{array}$ & $\begin{array}{c}\text { Equipment } \\
\text { operation } \\
\text { Equipment } \\
\text { clean QAQC } \\
\text { Integrity/security }\end{array}$ & $\begin{array}{c}\text { Equipment } \\
\text { operation } \\
\text { Equipment } \\
\text { clean QAQC } \\
\text { Integrity/security }\end{array}$ & $\begin{array}{l}\text { Equipment } \\
\text { operation } \\
\text { Equipment } \\
\text { clean QAQC } \\
\text { Integrity/security }\end{array}$ \\
\hline \multicolumn{2}{|c|}{ Sampling errors } & $\begin{array}{l}\text { In-situ nugget } \\
\text { effect FSE, GSE } \\
\text { DE, EE, WE }\end{array}$ & PE & $\begin{array}{c}\text { FSE, GSE DE, } \\
\text { EE, WE, PE }\end{array}$ & $\begin{array}{c}\text { FSE, GSE DE, } \\
\text { EE, WE, PE }\end{array}$ & PE AE \\
\hline \multicolumn{2}{|c|}{ Dominant effect on results } & Precision Bias & Bias & $\begin{array}{c}\text { Precision (if } \\
\text { splitting) Bias }\end{array}$ & $\begin{array}{l}\text { Precision (if } \\
\text { splitting) Bias }\end{array}$ & Bias \\
\hline \multicolumn{2}{|c|}{ Material risk assuming average practice } & High & Low & Moderate & Moderate & Low \\
\hline \multicolumn{2}{|c|}{ Material risk assuming optimised practice } & Moderate & Low & Low & Low & Low \\
\hline
\end{tabular}

The heterogeneity or variability of a given variable (e.g., grade, density) can be quantified by the nugget effect and has a direct link to TOS $[54,55,58]$. The nugget effect is a quantitative geostatistical term describing the inherent variability between samples at very small separation distances, though in reality has a wider remit than just differences between contiguous samples. The magnitude of the total nugget effect relates to the geological or in-situ nugget effect (GNE) and the sampling nugget effect (SNE).

The GNE relates to [55,58]:

○ Distribution of single mineral grains or clusters distributed through the ore domain(s).

$\bigcirc$ Continuity of structures or domains such as high-grade carriers within the main host structure or vein-lets within wall rocks.

The SNE relates to $[55,58]$ :

- Sample support (sample size-volume-variance). 
- Sample density (number of samples at a given spacing-information effect).

- Sample collection, preparation, testwork, and assay procedures.

A high GNE leads to high data variability, particularly where samples are too small and protocols not optimised. The SNE component is related to errors induced by inadequate sample size, sample collection, preparation methods, and measurement procedures. Throughout the MVC, optimised sampling protocols aim to reduce the SNE, thereby also reducing total nugget variance, skewness of the data distribution, and number of extreme data values $[22,42,55,56,58]$.

\subsubsection{Geometallurgical Sampling}

In the geometallurgical context, samples are taken for both direct testing (e.g., grade, comminution, recovery, and geoenvironmental parameter determination) or for proxy measurement (e.g., EQUOtip to correlate with hardness; Table 7). Samples have varying supports and spatial coverage, and thus resolution of variability.

Table 7. Geometallurgical sampling matrix (modified from Keeney [40]).

\begin{tabular}{|c|c|c|c|c|c|c|}
\hline Type & Description & $\begin{array}{l}\text { Relationship } \\
\text { to Processing }\end{array}$ & $\begin{array}{l}\text { Cost per } \\
\text { Sample }\end{array}$ & $\begin{array}{l}\text { Number of } \\
\text { Samples }\end{array}$ & Sample Support & $\begin{array}{l}\text { Spatial } \\
\text { Coverage }\end{array}$ \\
\hline Level 4 & $\begin{array}{l}\text { Core composites } \\
\text { for metallurgical } \\
\text { testwork }\end{array}$ & Direct & High & Low & $\begin{array}{c}\text { Domain or } \\
\text { variability } \\
\text { composites }(>50 \mathrm{~kg})\end{array}$ & Very limited \\
\hline Level 3 & $\begin{array}{l}\text { Discontinuous } \\
\text { core intervals for } \\
\text { physical testwork }\end{array}$ & Direct & Moderate & Low-moderate & $\begin{array}{l}\text { Relatively short } \\
\text { lengths }(<1 \mathrm{~m})\end{array}$ & Limited \\
\hline Level 2 & $\begin{array}{l}\text { Continuous } \\
\text { core-based } \\
\text { measurements }\end{array}$ & Proxies & Low & High & $\begin{array}{c}\text { Measurements taken } \\
\text { along entire core } \\
\text { length, potentially } \\
100 \mathrm{~s} \mathrm{~m}\end{array}$ & Very good \\
\hline Level 1 & Continuous core & Direct & Low & High & $\begin{array}{l}1-2 \text { m continuous } \\
\text { core composites }\end{array}$ & Very good \\
\hline
\end{tabular}

Traditional metallurgical samples are generally Level 3 or 4 types, being relatively large and of limited spatial distribution (Table 7). Level 1 and 2 samples are the most valuable for developing geometallurgical block models, as they relate to drill core throughout the mineralised (and diluting) domains.

\subsubsection{Programme Quality Assurance/Quality Control}

Quality assurance/quality control (QA/QC) is critical throughout all programmes. Metallurgical sampling and testwork should be fully integrated into geometallurgical studies. The necessity for quality management is relatively well understood by most mining professionals. There are a number of tools available for those managing grade data; though in some cases there is minimal understanding of why quality control activities are being undertaken or how to interpret the results. Traditional metallurgical testwork is critical for plant design and is an inherent part of geometallurgy. In a geometallurgical study, multiple spatially distributed small-scale tests are used as proxies for process parameters. These will be validated against traditional testwork results. Quality management practices now need to be applied to geometallurgical variables, which requires application of the concepts of TOS and statistical process control. Ehrig, Liebezeit and Macmillan and Dominy et al. make some general recommendations to this end [22,23,59].

Errors are additive throughout the sampling value chain and generate both monetary and intangible losses. The aim is to collect representative samples to accurately describe the material in question. Sample collection is followed by reduction in both mass and fragment size to provide a sub-sample for testwork or assay. This entire process can be particularly challenging in the low-grade environment (e.g., precious metals) and may require special protocols. 


\subsubsection{Compliance with Reporting Codes}

Given that most geometallurgical activities feed into economic studies and resource/reserve estimates that will be publicly reported, it is important to ensure that the data produced are fit-for-purpose. The public reporting of metallurgical sample and testwork results are as important as grade results, but frequently receive less rigor. The JORC 2012 Code has global application for the reporting of exploration results, Mineral Resources, and Ore Reserves [60]. It requires the Competent Person(s) to provide commentary on any sampling, testwork, and assaying process. From a geometallurgical perspective, Table 1 (Section 4) of The Code [60] requires disclosure of metallurgical factors and assumptions as part of reporting Ore Reserves (Table 8).

Table 8. Extract from The JORC Code Table 1 (Section 4) pertaining to metallurgical testwork [60].

\begin{tabular}{cll}
\hline 1 & $\begin{array}{l}\text { The metallurgical process proposed and the appropriateness } \\
\text { of that process to the style of mineralisation }\end{array}$ \\
\hline 2 & $\begin{array}{l}\text { Whether the metallurgical process is well-tested technology or } \\
\text { novel in nature }\end{array}$ \\
$\begin{array}{c}\text { Metallurgical factors } \\
\text { or assumptions }\end{array}$ & $\begin{array}{l}\text { The nature, amount, and representativeness of metallurgical } \\
\text { test work undertaken, the nature of the metallurgical } \\
\text { domaining applied, and the corresponding metallurgical } \\
\text { recovery factors applied }\end{array}$ \\
\cline { 2 - 4 } & \begin{tabular}{l} 
Any assumptions or allowances made for deleterious elements \\
\hline 5
\end{tabular} & $\begin{array}{l}\text { The existence of any bulk sample or pilot scale test work and } \\
\text { the degree to which such samples are considered } \\
\text { representative of the orebody as a whole }\end{array}$ \\
\hline $6 \quad \begin{array}{l}\text { For minerals that are defined by a specification, has the ore } \\
\text { reserve estimation been based on the appropriate mineralogy } \\
\text { to meet the specifications? }\end{array}$ \\
\hline
\end{tabular}

Items (3) and (5) in Table 8 are the most relevant to geometallurgical sampling, testwork, and assay programmes. Item (3) looks for clarification around the "what, where, and how" of sampling, whereas (5) focusses on validation via bulk sampling and/or pilot work. Both look for some discussion on representativity. Item 3 requires specific comment on the representativity of metallurgical samples and in addition, criteria listed in The Code Table 1-Section 1 ("Sampling Techniques and Data") [60] are also relevant. Project study reports often fail to detail the spatial extent of metallurgical sampling, or the number of composites collected and their relative masses. It is common for a feasibility study report to state that "the sampling and testwork programmes have been extensive and due care was taken in selecting and compositing representative samples" with little justification as to why samples are considered representative [23].

There is now a need to move towards proper quantification of geometallurgical sampling, testwork, and analytical errors. The new DS3077 horizontal standard provides a framework on which to produce transparent protocols and develop rigorous QA/QC [61].

\subsection{Ore and Waste Characterisation}

\subsubsection{Analysis of Textures}

Characterisation of whole rock and processed materials provide benchmark understanding of the ore and its subsequent performance in the plant. By analysing these two materials specifically, opportunities are presented to better understand the processing behaviours and deportments.

The textures of ore influence its beneficiation and flotation performances, the quality of the concentrate, and provide an indication of tailings characteristics. A common understanding of the term "texture" relates to the grain size, which can be coarse, medium, or fine-grained, with varying grain 
shapes. Alternatively, some describe textures in a mineralogical sense, i.e., high clay, quartz, or mica. The term texture is not a one-size-fits-all description, but it must be clear what it is and be consistent. Texture should include descriptors relating to structural features. For example, these could be forms of discontinuities (e.g., fractures or faults) and/or intruded features such as veins. Tighter definitions need to be derived; new definitions of textures or structural features would ideally be owned deposit to deposit, though there will be similarities between like deposits (i.e., porphyry to porphyry).

Here it is suggested that textures are characterised on three scales: macro-, meso-, and micro-scale. Macro is mine-scale (e.g., pit bench or underground face; a geological scale), meso is core-scale, and micro-scale is particle and mineral grain sized. Rarely is texture utilised at bench or face scale, it is often introduced at the meso-scale and commonly used on the micro-scale. Texture is concerned with the relationships of minerals at particle to grain scale. It is the description of mineral intergrowths, associations and grain sizes, and disseminations and inclusions. An example of understanding textural issues is measuring a "problem mineral" which is microns in size, wholly locked into a target mineral in the concentrate. The problem mineral is then seen as a penalty in the concentrate. However, if identified sufficiently early during textural characterisation and analysis, it may be possible to reconfigure a circuit and insert suitable processes or technologies to remove those minerals from going further downstream. Automated methodologies for the analysis and classification of rock textures are now being developed $[62,63]$.

\subsubsection{Advanced Mineralogical Characterisation}

Mineral characterisation is a significant part of any geometallurgical programme at any stage in the MVC. There are several methods for collecting mineralogical data and imagery, in an operational environment and in laboratory setting. These data could be in the form of raw data for processing, providing large data sets and image files to correspond.

A wealth of information and data came into existence with the development of Automated Mineralogical Analysis (AMA) around thirty years ago. This has proved to be a very successful analytical tool which is still used and under development today. AMA is deemed a routine tool and utilises scanning electron microscopy (e.g., TIMA, Mineralogic, MLA, and QEMSCAN) [64]. AMA are specialised systems with software designed exclusively for the characterisation of ores. Specific programmes are tailored for minerals of interest (e.g., Au), which present challenging textures, or rarity of abundance. Programmes may also be manipulated to capture the internal elemental differences through increasing X-ray measurement times. This is particularly useful when trying to understand stoichiometry/elemental substitutions, such as auriferous pyrite or Au grains with substituted elements.

A key outcome of geometallurgical data collection is the concomitant increase in orebody knowledge. The spatial mapping of geochemistry, mineralogy, and texture is central to the geometallurgical approach. The spatial understanding of mineralogy, texture, and other primary geological characteristics will result in enhanced genetic models and improved understanding of orebody paragenesis. Multi-element assays should be supplemented with mineralogical data, including quantitative XRD and AMA. This can be used to develop a set of assay-to-mineral conversion algorithms so that the mineral composition can be inferred.

While application of optical microscopy, AMA, and laser ablation (LA-ICP-MS) in conjunction with assay and geological logging data is a typical suite of tools, the use of high-resolution X-ray computed tomography (HRXCT) is recently being used in research to investigate a range of ore types [65].

HRXCT is useful when characterising textures for liberation studies, but also extremely useful for characterising rock mass for leaching purposes, whether that be heap leaching or in-situ potential [66]. The latter requires information about pore connectivity, providing a relationship between that and flow of lixiviants for metal recovery. 3D analysis provided by the HRXCT software allows a determination 
of particle shape or morphology and could provide key information about the best comminution approach and recovery practices thereafter $[65,67]$.

Continuous HRXCT scanning of drill core is the ultimate goal and will provide many advantages to a project across early stage commencement, automation, and speed. Semi-continuous scanning is now possible via the OreXplore ${ }^{\mathrm{TM}}$ system. The combined HRXCT and XRF unit is capable of scanning four one-metre lengths of up to NQ size core in one session. The HRXCT component provides 3D imaging of mineral shape and distribution, texture, and structural features supported by elemental analysis. Mineral particle resolution by HRXCT is around $200 \mu \mathrm{m}$, though this is dependent upon a number of factors. XRF detection limits are around 10 ppm (e.g., Mo, Sn and Sb) or 100 ppm (e.g., As, $\mathrm{Pb}, \mathrm{W}$ and $\mathrm{Zn}$ ) for base metals. At the current time, the detection limit for $\mathrm{Au}$ is $100 \mathrm{ppm}$ and $\mathrm{Ag} 10$ $\mathrm{ppm}$. The application of specific software provides a visualisation platform, which allows interrogation of the mineralogy, texture, and structure with elemental composition.

\subsubsection{Automated Core Scanning}

Much non-grade information derived from drill core is a function of visual inspection as part of geological and geotechnical logging. Visual logging is generally highly subjective, experience-based, and often conducted by relatively junior personnel. Automated core logging, across short wave length infrared reflectance, thermal infrared reflectance, and petrophysical technologies, are playing an increased role in characterisation across geological and engineering parameters [68-72]. For example, the HyLogger ${ }^{\mathrm{TM}}$ automated spectral analysis and imaging system collects systematic short wave length infrared reflectance spectra [73]. These can be classified into the dominant responsive mineral species and their compositional variations (e.g., chlorites, white micas, and clays).

Distribution of "soft" responsive phases show relationships to comminution behaviour related to decrease of bulk strength [69]. Such information can also be used alongside assay data to enable the prediction of geoenvironmental characteristics (i.e., the propensity of a unit to offer neutralising capacity) as documented in Parbhakar-Fox and Lottermoser [74]. More recently, classified mineralogy information from drill core obtained from Corescan ${ }^{\mathrm{TM}}$ have been used to develop new geoenvironmental indexes including the geoenvironmental domaining index [71] and the automated acid rock drainage index $[75,76]$, which alleviate issues associated with subjective logging. Developing additional machine learning algorithms to predict other geometallurgical indices represents a future direction for the mining industry which is being facilitated by the ability of new computing platforms to process big data.

\subsubsection{Down-the-Hole Prediction}

Data collection for down-the-hole (DTH) or measure-while-drilling (MWD) is under continuous development. Over the last decade established methods have been created, such as understanding rock hardness and rock mass through rate of penetration (ROP) and torque [77]. Techniques are starting to differentiate lithologies using petrophysics and fuzzy interference systems by applying multivariate analysis, neuro-adaptive learning algorithms, and/or machine learning [78-80]. MWD real-time data can be processed and provide an approximation of rock strength whilst physically drilling [81]. Sensors collecting data are related to pressures on the bit, torque, and speed or ROP. Machine-learning practices are being utilised to discriminate geology/lithologies from the real-time MWD data. If proven to successfully (with high confidence) differentiate geologies consistently, the data can be integrated into ore body knowledge systems, including engineering geology and geotechnical engineering as well as infrastructure projects. Neural networks and deep learning systems afford the opportunity to create more certainty from uncertain data, which is ideal for lithological and geological mapping and discrimination difficulties [82]. 


\subsection{Domains and Models}

\subsubsection{Domains}

In a geometallurgical programme, key aspects such as sample selection and testwork, domaining, definition of response variables, and modelling must be optimised to the data spacing and output required (e.g., Figure 3: resolution, variability, and project stage). The design of a programme will vary from deposit to deposit dependent upon degree of complexity and heterogeneity, where no singular approach is applicable globally.

Traditionally, the modelling of an ore body has been restricted to the geological domain: the definition of physical regions with homogeneous properties based on lithology, mineral grade, and style of mineralisation, densities, and grade(s). Processing domains are less often defined and are a key output of the geometallurgical approach (Figure 2). The selection of a modelling approach for geological, grade, and processing properties in 3D space involves a trade-off between geological realism and conditioning capabilities.

Geometallurgy emphasises the need for 3D models for mine and process optimisation with multiple, sometimes unconventional attributes. A key output of geometallurgical modelling is the definition of geometallurgical domains. In principle, a geometallurgical domain is a 3D volume in which it is reasonable to assume that a particular variable comes from a homogenous population (Figure 1). Generic volumetric 3D domains based on a geological variable(s) such as lithology or alteration may or may not be statistically homogenous for the parameter(s) in question. A process-specific domain is a $3 \mathrm{D}$ volume where the variable under consideration (e.g., flotation recovery) comes from a statistically-homogenous population. The geological drivers of the response variables will have to be resolved during domain definition.

Mineral deposits are typically multivariate systems with many factors contributing to their overall complexity. A deposit can cut across several lithological units and have differing mineralisation and alteration styles, which will affect metallurgical response. Using lithological boundaries to control the distribution of metallurgical indices and testwork without effective evaluation may prove erroneous. Early stage geometallurgical domains are more likely to correlate with lithology and/or mineralisation/alteration style (Figure 1). Note that comminution and recovery domains may be different. In practice, geometallurgical domains are qualitative attributes which have to be amenable to spatial block modelling.

\subsubsection{Models}

Complementing the traditional grade model, geometallurgical block models display the distribution of key metallurgical and mining parameters throughout the orebody to support financial analysis and mine planning [13,83,84]. Coward and Dowd summarise an approach to geometallurgical modelling as [13]:

- Identify the variables required to understand critical process responses.

- Sample and measure these variables.

- Develop techniques to estimate and simulate these characteristics spatially at the correct scale and incorporate the values into block models.

The traditional modelling approach considers a single or deterministic estimate (e.g., the kriging mean) which does not effectively represent variability. Smoothed kriged models will generally be insufficient for optimising processing operations in heterogeneous mineralisation. A model which underestimates variability will understate the local variation in properties, which should be considered in the design and operation of the mine and plant. In addition to estimates with too low variability, kriging may introduce a bias for variables such as metallurgical properties, which do not combine linearly $[25,85]$. Geometallurgical domains may be more optimally defined via conditional simulation, 
which provides multiple outcomes for scenario evaluation [86,87]. Such an approach provides a better opportunity to determine how NPV changes across various scenarios.

While resource models focus on modelling of the primary variables that drive metallurgical responses, building of geometallurgical models separately may involve direct modelling of response variables in the 3D block model [25]. A complication with the estimation of response variables with classic techniques based on a variogram is their non-additivity $[25,86,87]$. Hence caution is required if undertaking the direct modelling of response variables. This can complicate the definition of geometallurgical domains which may benefit from fuzzy classification algorithms such as the Gustafson-Kessel clustering algorithm [88]. Some recent developments in multivariate domaining are reported by Sepulveda et al. and Addo et al. [89,90].

Much of the sustainability and energy efficiency dimensions derived from geometallurgy are driven by mineralogy. While grade may be a useful proxy for mineralogy, it is not necessarily the most appropriate attribute to use during estimation of recovery. In general, mineral grades (e.g., percentage bornite) are more effective as these are additive, which makes modelling of this primary variable relatively straightforward $[25,85]$.

It is critical to ensure that the entire geometallurgical process, inclusive of data collection and test work, data storage and interpretation, and modelling and analyses are of the highest quality to ensure that any Mineral Resource and Ore Reserve estimates and subsequent economic studies can be reported in accordance with the JORC Code 2012 or other international reporting code as appropriate $[8,22,44,60]$. Most importantly, the modelling of key variables (e.g., rock mass parameters, density, metal recovery, and hardness) provides a more efficient method to convert Mineral Resources to Ore (Mineral) Reserves beyond the simplistic application of average modifying factors.

\subsection{Financial Modelling}

In the simplest sense, the net revenue from a mine or block relates to metal content, recovery and price, less operating costs, penalties, and royalties:

Net Revenue $=($ Metal content $\times$ Recovery $\times$ Price $)-($ Operating cost - Penalties - Royalties $)$

All aspects of this simple relationship link in with geometallurgical modelling where metal content is grade (which may be variable), recovery relates to ore properties (e.g., a function of mineralogy, grade, texture, and process conditions), operating costs relate to mining and processing (e.g., mining method and capacity, geotechnical conditions, plant throughput, plant circuit, etc.), and penalties relate to deleterious elements in the product (e.g., ore mineralogy and chemistry). A major input into operating cost is that of plant throughput, which is a function of rock parameters (e.g., density, $A^{*} b$, $\mathrm{BWi}$, and feed/product size), machine parameters (e.g., mill dimensions, speed, load and feed load), and plant circuit. Grinding energy is a major factor in operating cost, so its optimisation and prediction in the geometallurgical model is critical [3,91,92]. Metal price and royalties lie outside of technical prediction, though are of course important. Most of the revenue inputs can be modelled on a block by block basis to provide a "value" based model [18].

Deterministic modelling that provides a single project NPV does not capture small-scale (e.g., SMU) variability, orebody variability, or process uncertainty. Whereas a scenario based approach backed by simulation provides for NPV distributions, both on the block by block-scale and across the LOM [12,13]. Block models form the basis for project economic evaluation. Approaches such as scenario thinking to project evaluation encourages the project team to re-perceive the systems aspects of the project and allows empirical testing of different strategies [4]. This can be achieved by modelling spatial variability and uncertainty of the deposit throughout the value chain. Modelling seeks high NPV options that are robust in the face of potential scenarios across the LOM [93]. 


\subsection{Acid and Metalliferous Drainage Prediction}

Undertaking effective environmental ore characterisation at the pre-feasibility and feasibility stages is essential for both efficient mine operations and reducing environmental impacts after mine closure. Environmental parameters requiring characterisation include the propensity of a rock unit to generate acid, mapping deleterious element deportment, and characterising the release of toxic dusts as a result of blasting $[50,94]$. However, AMD prediction is not a one-test discipline, a combination of static tests is typically performed to permit sample classification. Consequently, the number of samples typically put through a static testing programme may be compromised, resulting in inadequate characterisation of the AMD risks posed by future waste materials [50,51].

In general, static testing enables the definition of waste units. Longer-term (i.e., $>30$ weeks) kinetic tests may be performed on select waste materials (e.g., samples from waste units recognised as PAF) at the earlier LOM stages. Collectively, these help to predict the AMD characteristics of waste units, informing waste engineering and waste handling/scheduling plans. However, limitations with these methodologies have been recognised and have been discussed in the literature with the increasing use of mineralogy promoted as a means to overcome these $[50,53,95]$. Ultimately, integration of mineralogical, chemical, textural, and geometallurgical data will facilitate the most accurate and efficient AMD classifications as proposed by Parbhakar-Fox, therefore enabling mine operators to plan for closure based on geological properties [96].

\subsection{Waste Management and Recycling}

An emerging area for geometallurgy is the modelling of some of our most obvious and dormant resources-tailings storage facilities [97]. The success of using geometallurgy to model tailings facilities has been well-noted. There is huge potential to apply geometallurgical methodologies to better understand the location and character of a wealth of saleable metals and minerals.

Characterising tailings storage facilities will also introduce other operational stakeholders into the project, such as geophysicists and geochemists. As tailings are a near-future resource for many mining operations (e.g., Savage River mine, Tasmania; Rosebery mine, Tasmania; Century mine, Queensland), the area should be investigated, funded, and researched now with operators encouraged to explore for commodities other than that being mined (e.g., critical metals in base metal deposits) [94,98]. Mineral processing technologies and deficiencies have changed so much since many of the tailings facilities were constructed that there is significant potential for reserves, with biohydrometallurgical methods particularly well suited to extracted refractory metals [99]. Tailings dams and tailings storage areas could be considered the next deposit for some key metals, though their effective evaluation can be challenging [51].

\subsection{The Digital Mine}

The digital mine is high on the agenda of many companies. From a geometallurgical ore control perspective, the current drill or face sampling and assaying can feed into the digital realm, but only once the final assay is completed in the laboratory. Assay data can be interfaced with digital photographs, outputs from automated mapping, and surveys. Once into the digital platform, then artificial intelligence may allow direct feed into development control and design, and grade models. Data analytics will play a role in integrating and analysing grade and other data to produce more effective and agile short-term mine plans, potentially real-time information, and lead to automated reconciliation. Sensors in drill holes, at the mine face and in the plant will be critical for this development [100]. 


\section{Managing Geometallurgical Programmes}

\subsection{Overview}

A key aspect of any effective geometallurgical programme are multi-disciplinary teams, thus bringing together exploration and mining geologists, mining and geotechnical engineers, metallurgists and mineral process engineers, financial modellers, economists, and risk specialists [9]. By drawing on different disciplines and on specialists from other areas (for example, data mining/analytics and computing specialists, mathematical modellers and risk specialists) geometallurgy also sees industry practitioners, consultants, service providers, and academics working closely together. The key to the success of geometallurgical programmes is that of project management in its broadest sense. Large strategic programmes form the basis of feasibility studies, for example, and therefore require both effective people and data management.

\subsection{Geometallurgical Education}

Incorporating a highly applied discipline and subject such as geometallurgy into a university's curriculum is extremely challenging. There are trains of thought in so far as students should be made aware of geometallurgy as soon as reasonably possible. On the other side, they need to understand fundamentals and grasp concepts well in order to apply those key learnings to the world of geometallurgy. New initiatives in mining and extractive metallurgy courses must be sought and the inclusion of core and elective geometallurgy units is required. Integrating geometallurgy theory and practice would probably best suit final year undergraduate and post graduate students; at this point in education, their ability to approach problems through systemic thinking, logic, and to handle large data sets would be at an appropriate level. Many university courses in geometallurgy, or including a geometallurgical element, are still focussed on the more traditional "geology-mineralogy plus metallurgy" approach and fail to convey the LOM optimisation and 3D nature of geometallurgy.

There are more industry roles asking for geometallurgical knowledge and practical experience now more than ever. However, academics both trained and experienced in geometallurgical practice are few, so academia should be looking for assistance from industry to put back into the system through sessional training, workshops, and lecturing. A number of global universities offer geometallurgical modules, particularly at Masters degree level, however few if any offer this training in a true multi-disciplinary context. For example, offering a geometallurgical course to minerals engineers without putting it into the 3D spatial and mine planning context fails to communicate the real value of geometallurgy. Similarly, providing a geoscience-based approach with sole focus on mineralogy and geochemistry also fails. All aspects are relevant but must be presented in the full geometallurgical context.

University courses can be inflexible and hard to change. It is via direct industry feedback and the Alumni groups that proposed changes can be voiced, influencing the development of new units delivered. Included in this is educating site personnel who do not have the ability to leave site for further education and development. In parallel with voicing feedback of the requirement for geometallurgical programmes/units, universities need to understand the delivery expectations, i.e., online or blended learning. Experience would suggest that any online learning in the geometallurgical discipline should be reserved for post graduate level alone

\subsection{Geometallurgical Challenges}

The major challenges and areas of development within geometallurgy are:

- Gaining corporate support-projects may require separate financing.

- Geometallurgical teaching-integration across disciplines, including emerging disciplines such as data analytics, artificial intelligence, machine learning, and automation. 
- Implementation of studies across a wide range of technical disciplines (e.g., silos) and ensuring silos are broken down to effect data sharing and optimal communication.

- Application across feasibility studies and mine operations.

- Representative sampling programmes and effective ore/waste characterisation.

- Ensuring fit-for-purpose data through proper procedures and QA/QC programmes.

- Integration and interpretation of very large databases.

- Modelling/simulation of numerous different data types.

- Process and mine optimisation tools.

- Developing effective innovations across characterisation, data collection, and modelling, including data analytics, artificial intelligence, and machine learning.

- Ensuring that geometallurgical programmes are fit for purpose and can be reported in accordance with The JORC (2012) or other reporting codes.

\subsection{The Future of Geometallurgy}

The future sees more challenging and complex deposits being developed, where variability in both orebody and external factors will be material to profitability and sustainability. The data-rich nature of geometallurgy allows orebody variability to be incorporated into an optimised LOM plan.

"Future" geometallurgy sees a more advanced, "modern" geometallurgy driven by the digital mine. Technology will play a key role in automated characterisation during the strategic phase, and more real-time analysis during the tactical phase. More efficient data analytics will see improved use of orebody knowledge and integration of block models, economic studies, and mine and plant optimisation. Operations (tactical) will see emphasis on data analytics that will play a key role in integrating and analysing grade and other data to produce more effective and agile short-term mine plans, potentially real-time information, and lead to automated updating and reconciliation. Sensors in drill holes, at the mine face, and in the plant are critical for this development.

The multi-disciplinary nature of geometallurgy will grow as it will need to include non-traditional expertise in data analytics, machine learning, software engineering, and automation. A new breed of mining professionals will emerge with different technical mining skills, but also with an understanding of non-traditional expertise. Corporate accountability, particularly for public companies, will continue to increase, thus geometallurgy should ultimately be embedded into international reporting codes (e.g., The JORC Code 2012) [60].

Geometallurgy will find greater application in small underground mines (e.g., $<150,000$ t per annum production), as such deposits are slowly finding favour again given that they generally have smaller footprints, are relatively high grade, and relate to brownfield areas. For small mines, the strategic versus tactical approach is still relevant, though may be via a geometallurgy "lite" application to provide resolution of a few key parameters compared to a large deposit/mine [22].

Geoenvironmental application of geometallurgy is becoming a non-negotiable activity as part of the LOM licence to operate. Undertaking effective geoenvironmental ore/waste characterisation at the strategic phase is essential for both efficient mine operations and reducing environmental impacts after mine closure.

\section{Conclusions}

(1) Geometallurgy is the integration and utilisation of geological, metallurgical, environmental, and economic information to maximise the value of an orebody, to minimise technical and operational risk, and build a resilient operation. Through a multi-disciplinary approach, it identifies attributes that contribute to the realised value of a resource and enables ore variability to be factored into the flowsheet, infrastructure design, and the production and quality forecasts over the LOM. This includes traditional attributes, such as grade, as well as process factors such as hardness (e.g., 
crushability and grindability), mineral species and abundance, mineral liberation, metallurgical recovery, concentration of deleterious elements, and acid generating and neutralising potential.

(2) Geometallurgy has reached a maturity beyond a "geology-mineralogy plus metallurgy" activity, though the input and integration of the two is critical. It is recognised as an approach that can both maximise value and predict the risks associated with resource development and mine operations. It is not a "quick fix", but a long-term commitment to adding value. Geometallurgy complements, but does not replace, existing approaches to design and optimisation of mining and processing operations. Critically, geometallurgical issues vary from one deposit to another, thus there is no fit-all template that can be used.

(3) Key drivers for the geometallurgical approach relate to lower grades and geologically and / or metallurgically more complex orebodies; high grade and metallurgical response variability; increased capital costs and declining profit margins, thus higher financial risk; and the need for well-managed project risk to attract funding.

(4) The process of ore variability testing for metallurgical response and the use of fast, inexpensive metallurgical proxies have been developed in the past decade. Technology continues to advance, and techniques such as hand-held analytical tools, automated core scanning, and down-the-hole measurements allow for faster, less expensive testing.

(5) There is general acceptance within the mining industry that assumed modifying factors defined by the 2012 JORC Code are not sufficient to mitigate the risk of funding projects. The geometallurgical approach is to move away from factored Ore Reserves to data-rich block models providing information for mining, metallurgical, and environmental considerations. Uncertainty models can be derived from this data to support the classification of geometallurgical parameters such as throughput and recovery into reserve categories. The application of geometallurgy generally has the favourable consequence of increasing Mineral Resource to Ore Reserve conversion.

(6) The future sees more challenging and complex deposits being developed, where variability in both orebody and external factors will be material. The data-rich nature of geometallurgy allows orebody variability to be incorporated into an optimised mine plan. The geometallurgical approach has tended to be used on large multi-million tonne type deposits, though is now becoming applied more to smaller deposits and across different commodities.

(7) Geometallurgy encompasses activities that utilise improved understanding of the properties of ore and waste, which impact positively or negatively on the value of the product, concentrate, or metal. Properties not only include those that impact on processing efficiency, but also those of materials which will impact upon other actions such as rock stability, blasting, and waste disposal. Companies that embrace the geometallurgical approach will benefit from increased shareholder value.

(8) Geometallurgy leads to improved team work and communication during project studies and mining. It straddles diverse technical and managerial areas, optimising exploitation by taking an holistic view. Additionally, geometallurgy aims to identify and mitigate technical risk during project development and production. These objectives require strong cross-technical domain communication driven by professionals with the correct technical and leadership skills.

(9) The application of geometallurgy across the MVC aims to improve project resilience and success through a number of ways:

- Identify orebody variability and develop strategies to mitigate the risks (e.g., collect additional data; revise the mine plan; adapt or change the process strategy, or engineer flexibility into the system).

- Identify system constraints and how these impact on performance across the MVC and allow project re-engineering to reduce or eliminate such constraints.

- Assess financial options to support the operation from construction through to sustainable production. 
Author Contributions: S.C.D. conceived the paper. L.O. wrote the mineralogical and textural related matter. S.C.D. and H.J.G. wrote the sampling and modelling related matter. S.P. wrote the financial related matter. A.P.-F. wrote sections relating to geoenvironmental matters. All authors contributed to writing and editing of the paper.

Funding: A.P.-F. was supported by the ARC Research Hub for Transforming the Mining Value Chain at the University of Tasmania (project number IH130200004).

Acknowledgments: The authors acknowledge a number of companies across Australia, Africa, the Americas, East Asia, and Europe for the opportunity to input into geometallurgical programmes. Thanks are due to the three Minerals reviewers for helpful comments on the manuscript.

Conflicts of Interest: The authors declare no conflict of interest.

\section{Abbreviations}

The following abbreviations are used in this manuscript:

\begin{tabular}{|c|c|}
\hline$A^{*} b$ & Impact indices derived from SMC test \\
\hline $\mathrm{Ai}$ & Abrasion index \\
\hline AMA & Automated mineralogical analysis \\
\hline AMD & Acid mine drainage \\
\hline BWi & Bond work index \\
\hline CAPEX & Capital expenditure \\
\hline EQUOtip & EQUOtip hardness tester \\
\hline FS & Feasibility study \\
\hline GEOTEK & Core imaging system \\
\hline GNE & Geological (or in-situ) nugget effect \\
\hline GRG & Gravity recoverable gold \\
\hline HRXCT & High resolution $\mathrm{X}$-ray computed tomography \\
\hline JKCI & JK comminution index \\
\hline JKFI & JK floatability index \\
\hline JKRBT & JK rock breakage test \\
\hline JORC & Joint Ore Reserves Committee, The JORC Code 2012 [60] \\
\hline (LA)-ICPAES/MS & (Laser ablation)-Inductively coupled atomic emission/mass spectrometry \\
\hline LIBS & Laser induced backscatter spectroscopy \\
\hline LOM & Life-of-mine \\
\hline MLA & Mineral liberation analysis \\
\hline MVC & Mine value chain \\
\hline MWD & Measure while drilling \\
\hline NAF & Net acid forming \\
\hline NPV & Net Present Value \\
\hline PAF & Potentially acid forming \\
\hline PFS & Pre-feasibility study \\
\hline PXRF & Portable X-ray florescence \\
\hline RQD & Rock quality designation \\
\hline SEM & Scanning electron microscopy \\
\hline SG & Specific gravity \\
\hline SMC & SAG mill comminution test \\
\hline SMU & Selective mining unit \\
\hline SNE & Sampling nugget effect \\
\hline SPI & SAG power index \\
\hline TIMA & Tescan integrated mineral analysis system \\
\hline TOS & Theory of Sampling (individual TOS errors defined in Table 3) \\
\hline $\mathrm{QA} / \mathrm{QC}$ & Quality assurance/quality control \\
\hline Q/PXRD & Quantitative/portable X-ray diffraction \\
\hline
\end{tabular}




\section{References}

1. Ehrig, K. Geometallurgy-What do you really need to know from exploration through to production. In We are Metallurgists, Not Magicians; Australasian Institute of Mining and Metallurgy: Melbourne, Australia, 2018; pp. 33-36.

2. Ashley, K.J.; Callow, M.I. Ore variability: Excercises in geometallurgy. Eng. Min. J. 2000, 201, 24-28.

3. Bye, A.R. Case studies demonstrating value from geometallurgy initiatives. In Proceedings of the International Geometallurgy Conference, Brisbane, Australia, 5-7 September 2011; Australasian Institute of Mining and Metallurgy: Melbourne, Australia, 2011; pp. 3-90.

4. Vann, J.; Jackson, S.; Bye, A.; Coward, S.; Moayer, S.; Nicholas, G.; Wolff, R. Scenario thinking-A powerful tool for strategic planning and evaluation of mining projects and operations. In Proceedings of the Project Evaluation Conference, Melbourne, Australia, 24-25 May 2012; Australasian Institute of Mining and Metallurgy: Melbourne, Australia, 2012; pp. 5-14.

5. Rendu, J.-M. Risk Management in Evaluating Mineral Deposits; Society of Mining, Metallurgy and Exploration: Englewood, CO, USA, 2017; p. 310.

6. Walters, S. An overview of new integrated geometallurgical research. In Proceedings of the International Congress for Applied Mineralogy, Brisbane, Australia, 8-10 September 2008; Australasian Institute of Mining and Metallurgy: Melbourne, Australia, 2008; pp. 79-82.

7. Jackson, J.; McFarlane, A.; Olson Hoal, K. Geometallurgy_Back to the Future: Scoping and Communicating Geomet Programs. In Proceedings of the International Geometallurgy Conference, Burwood, Australia, 5-7 September 2011; Australasian Institute of Mining and Metallurgy: Melbourne, Australia, 2011; pp. 125-131.

8. Keeney, L. A geometallurgical methodology suitable for resource definition. SEG Newsl. 2013, 94, 18-19.

9. Williams, S.R. A historical perspective of the application and success of geometallurgical methodologies. In Proceedings of the International Geometallurgy Conference, Brisbane, Australia, 30 September-2 October 2013; Australasian Institute of Mining and Metallurgy: Melbourne, Australia, 2013; pp. 37-47.

10. Lund, C.; Lamberg, P. Geometallurgy-A tool for better resource efficiency. Eur. Geol. 2014, 37, 39-43.

11. Glass, H.J. Geometallurgy: Driving innovation in the mine value chain. In Proceedings of the International Geometallurgy Conference, Perth, Australia, 15-16 June 2016; Australasian Institute of Mining and Metallurgy: Melbourne, Australia, 2016; pp. 21-28.

12. Jackson, S.; Vann, J.E.; Coward, S.; Moayer, S. Scenario-based project evaluation-Full mineral value chain stochastic simulation to evaluate development and operational alternatives. In Proceedings of the International Mining Geology Conference, Adelaide, Australia, 18-20 August 2014; Australasian Institute of Mining and Metallurgy: Melbourne, Australia, 2014; pp. 1-11.

13. Coward, S.; Dowd, P.A. Geometallurgical models for the quantification of uncertainty in mining project value chains. In Proceedings of the APCOM Conference, Fairbanks, AK, USA, 23-27 May 2015; Society of Mining Engineers: Englewood, CO, USA, 2015; pp. 360-369.

14. Shi, F.; Kojovic, T.; Larbi-Bram, S.; Manlapig, E. Development of a rapid particle breakage characterisation device-The JKRBT. Miner. Eng. 2009, 22, 602-612. [CrossRef]

15. Kojovic, T.; Michaux, S.; Walters, S. Developments of new comminution testing methodologies for geometallurgical mapping of ore hardness and throughput. In Proceedings of the International Mineral Processing Congress, Brisbane, Australia, 6-10 September 2010; Australasian Institute of Mining and Metallurgy: Melbourne, Australia, 2010; pp. 891-899.

16. Bradshaw, D.J.; Vos, F. The development of a small scale test for rapid characterisation of flotation response (JKMSI). In Proceedings of the Canadian Mineral Processors Operators Conference, Ottawa, ON, Canada, 22-24 January 2013; Canadian Institute of Mining: Ottawa, ON, Canada, 2013; pp. 43-57.

17. Vos, C.F.; Stange, W.; Bradshaw, D.J. A new small-scale test to determine flotation performance: Overall performance. Miner. Eng. 2014, 66, 62-67. [CrossRef]

18. McKay, N.; Vann, J.; Ware, W.; Morley, C.; Hodkiewicz, P. Strategic versus tactical geometallurgy-A systematic process to add and sustain resource value. In Proceedings of the International Geometallurgy Conference, Perth, Australia, 15-16 June 2016; Australasian Institute of Mining and Metallurgy: Melbourne, Australia, 2016; pp. 29-36. 
19. Baumgartner, R.; Dusci, M.; Gressier, J.; Trueman, A.; Poos, S.; Brittan, M.; Mayata, P. Building a geometallurgical model for early-stage project development-A case study from the Canahuire epithermal $\mathrm{Au}-\mathrm{Cu}-\mathrm{Ag}$ deposit, Peru. In Proceedings of the International Geometallurgy Conference, Brisbane, Australia, 5-7 September 2011; Australasian Institute of Mining and Metallurgy: Melbourne, Australia, 2011; pp. 53-59.

20. King, G.S.; Macdonald, J.L. The business case for early-stage implementation of geometallurgy-An example from the Productora $\mathrm{Cu}-\mathrm{Au}-\mathrm{Mo}$ deposit, Chile. In Proceedings of the International Geometallurgy Conference, Perth, Australia, 15-16 June 2016; Australasian Institute of Mining and Metallurgy: Melbourne, Australia, 2016; pp. 125-133.

21. Dowd, P.A. Quantifying the impacts of uncertainty. In Handbook of Mathematical Geosciences; Springer Open: Cham, Switzerland, 2018; pp. 349-373.

22. Dominy, S.C.; O'Connor, L.; Glass, H.J.; Xie, Y. Geometallurgical study of a gravity recoverable gold orebody. Minerals 2018, 8, 186. [CrossRef]

23. Dominy, S.C.; O'Connor, L.; Glass, H.J.; Purevgerel, S.; Xie, Y. Towards representative metallurgical sampling and recovery testwork programmes. Minerals 2018, 8, 193. [CrossRef]

24. Kittler, P.; Liebezeit, V.; Ehrig, K.; Macmillan, E.; Lower, C. "It seemed like a good idea at the time ... "-Common mistakes in geometallurgy. In Proceedings of the International Geometallurgy Conference, Brisbane, Australia, 5-7 September 2011; Australasian Institute of Mining and Metallurgy: Melbourne, Australia, 2011; pp. 133-138.

25. Coward, S.; Vann, J.; Dunham, S.; Stewart, M. The primary-response framework for geometallurgical variables. In Proceedings of the International Mining Geology Conference, Perth, Australia, 17-19 August 2009; Australasian Institute of Mining and Metallurgy: Melbourne, Australia, 2009; pp. 109-113.

26. Hunt, J.; Kojovic, T.; Berry, R.J. Estimating comminution indices from ore mineralogy, chemistry and drill core logging. In Proceedings of the International Geometallurgy Conference, Brisbane, Australia, 30 September-2 October 2013; Australasian Institute of Mining and Metallurgy: Melbourne, Australia, 2013; pp. 173-176.

27. Keeney, L.; Nguyen, K. The use of EQUOtip as a hardness domaining tool. In Proceedings of the International Mineral Processing Congress, Santiago, Chile, 20-24 October 2014; GECAMIN: Santiago, Chile, 2014; pp. 128-138.

28. Mwanga, A.; Rosenkranz, J.; Lamberg, P. Testing of ore comminution behaviour in the geometallurgical context-A review. Minerals 2015, 5, 276-297. [CrossRef]

29. Aasly, K.; Ellefmo, S. Geometallurgy applied to industrial minerals operations. Mineralsproduksjon 2014, 5, A21-A34.

30. Butler, C.; Dale, R.; Robinson, S.; Turner, A. Geometallurgy_bridging the gap between mine and mill: A case study of the DeGrussa geometallurgy programme. In Proceedings of the International Geometallurgy Conference, Perth, Australia, 15-16 June 2016; Australasian Institute of Mining and Metallurgy: Melbourne, Australia, 2016; pp. 77-88.

31. Harbort, G.J.; Lam, K.; Sola, C. The use of geometallurgy to estimate comminution parameters within porphyry copper deposits. In Proceedings of the International Geometallurgy Conference, Brisbane, Australia, 30 September-2 October 2013; Australasian Institute of Mining and Metallurgy: Melbourne, Australia, 2013; pp. 217-230.

32. Macfarlane, A.S.; Williams, T.P. Optimising value on a copper mine by adopting a geometallurgical solution. J. South. Afr. Inst. Min. Metall. 2014, 114, 929-936.

33. Montoya, P.; Keeney, L.; Jahoda, R.; Hunt, J.; Berry, R.; Drews, U.; Chamberlain, V.; Leichliter, S. Geometallurgical modelling techniques applicable to pre-feasibility projects-La Colosa case study. In Proceedings of the International Geometallurgy Conference, Brisbane, Australia, 5-7 September 2011; Australasian Institute of Mining and Metallurgy: Melbourne, Australia, 2011; pp. 103-111.

34. Leichliter, S.; Larson, D. Geometallurgy for two recovery process operations at Cripple Creek and Victor gold mine. Min. Eng. 2013, 65, 29-33.

35. Liebezeit, V.; Ehrig, K.; Robertson, A.; Grant, D.; Smith, M.; Bruyn, H. Embedding geometallurgy into mine planning practices-Practical examples at Olympic Dam. In Proceedings of the International Geometallurgy Conference, Perth, Australia, 15-16 June 2016; Australasian Institute of Mining and Metallurgy: Melbourne, Australia, 2016; pp. 135-143. 
36. Lechuti-Tlhalerwa, R.B.; Gilika, O.; Field, M. Modelling geometallurgical variability of comminution parameters in Orapa kimberlite ore. In Proceedings of the Geometallurgy Conference, Cape Town, South Africa, 7-8 August 2018; Southern African Institure of Mining and Metallurgy: Johannesburg, South Africa, 2018; pp. 253-263.

37. Baumgartner, R.; Dusci, M.; Trueman, A.; Poos, S.; Brittan, M. Building a geometallurgical model for the Canahuire epithermal Au-Cu-Ag deposit, Peru-Past, present and future. In Proceedings of the International Geometallurgy Conference, Brisbane, Australia, 30 September-2 October 2013; Australasian Institute of Mining and Metallurgy: Melbourne, Australia, 2013; pp. 51-57.

38. Ehrig, K.; Liebezeit, V.; Smith, M.; Macmillan, E.; Lower, C. Geologists and the value chain-How material charaqcterisation by modern mineralogy can optimise design and operation of processing facilities. In Proceedings of the International Mining Geology Conference, Adelaide, South Australia, 18-20 August 2014; Australasian Institute of Mining and Metallurgy: Melbourne, Australia, 2014; pp. 5-13.

39. McCarthy, P. Managing technical risk for mine feasibility studies. In Proceedings of the Mining Risk Management Conference, Sydney, Australia, 9-12 September 2003; Australasian Institute of Mining and Metallurgy: Melbourne, Australia, 2003; pp. 21-27.

40. Keeney, L. The Development of a Novel Method for Integrating Geometallurgical Mapping and Orebody Mapping. Ph.D. Thesis, University of Queensland, Brisbane, Australia, 2010; p. 324.

41. Carrasco, C.; Keeney, L.; Walters, S. Development of geometallurgical laboratory tests to characterize metal preconcentration by size. In Proceedings of the International Mineral Processing Congress, Santiago, Chile, 20-24 October 2014; GECAMIN: Santiago, Chile, 2014; pp. 139-159.

42. Ehrig, K.; Pitard, F.F. Sampling the supergiant Olympic Dam iron-oxide Cu-U-Au-Ag deposit, South Australia. In Proceedings of the World Conference on Sampling and Blending, Perth, Australia, 9-11 May 2017; Australasian Institute of Mining and Metallurgy: Melbourne, Australia, 2017; pp. 21-27.

43. Liebezeit, V.; Smith, M.; Ehrig, K.; Kittler, P.; MacMillan, E.; Lower, C. Geometallurgy data management-A significant consideration. In Proceedings of the International Geometallurgy Conference, Brisbane, Australia, 5-7 September 2011; Australasian Institute of Mining and Metallurgy: Melbourne, Australia, 2011; pp. 237-245.

44. David, D. Geometallurgical guidelines for miners, geologists and process engineer-Discovery to design. In Mineral Resource and Ore Reserve Estimation Guide to Good Practice; Australasian Institute of Mining and Metallurgy: Melbourne, Australia, 2014; pp. 443-450.

45. Goers, M.; Almond, M. Bit to bag-The importance of a total coordinated system in RC drilling. In Proceedings of the Sampling Conference, Perth, Australia, 21-22 August 2012; Australasian Institute of Mining and Metallurgy: Melbourne, Australia, 2012; pp. 65-77.

46. Dominy, S.C.; Glass, H.J.; Lam, C.K.; O'Connor, L.; Purevgerel, S.; Minnitt, R.C.A. Integrating the Theory of Sampling into underground grade control strategies. Minerals 2018, 8, 232. [CrossRef]

47. Mudd, G.M. The Sustainability of Mining in Australia-Key Production Trends and Their Environmental Implications for the Future; Monash University and Mineral Policy Institute: Melbourne, Australia, 2009; p. 277.

48. Adiansyah, J.S.; Rosano, M.; Vink, S.; Keir, G. A framework for a sustainable approach to mine tailings management: Disposal strategies. J. Clean. Prod. 2015, 108, 1050-1062. [CrossRef]

49. Noble, T.L.; Parbhakar-Fox, A.; Berry, R.F.; Lottermoser, B.G. Mineral dust emissions at metalliferous mine sites. In Environmental Indicators in Metal Mining; Springer International: Cham, Switzerland, 2017; pp. 281-306.

50. Parbhakar-Fox, A.; Lottermoser, B.G. A critical review of acid rock drainage prediction methods and practices. Miner. Eng. 2015, 82, 107-124. [CrossRef]

51. Parbhakar-Fox, A.; Dominy, S.C. Sampling and blending in geoenvironmental campaigns-Current practice and future opportunities. In Proceedings of the World Conference on Sampling and Blending, Perth, Australia, 9-11 May 2017; Australasian Institute of Mining and Metallurgy: Melbourne, Australia, 2017; pp. 45-54.

52. Parbhakar-Fox, A.; Glen, J.; Raimondo, B. A Geometallurgical approach to tailings management: An example from the Savage River Fe-Ore mine, Western Tasmania. Minerals 2018, 8, 454. [CrossRef] 
53. Jackson, L.M.; Parbhakar-Fox, A.; Fox, N.; Cooke, D.R.; Harris, A.C. Assessing geoenvironmental risk using intact materials for early life-of-mine planning-A review of established techniques and emerging tools. In From Start to Finish: A Life-of-Mine Perspective; Australasian Institute of Mining and Metallurgy: Melbourne, Australia, 2018; pp. 1-18.

54. Gy, P.M. Sampling of Particulate Materials: Theory and Practice; Elsevier: Amsterdam, The Netherlands, 1982; p. 431.

55. Pitard, F.F. Pierre Gy's Sampling Theory and Sampling Practice; CRC Press: Boca Raton, FL, USA, 1993 ; p. 488.

56. Minnitt, R.C.A. Sampling: The impact on costs and decision making. J. South. Afr. Inst. Min. Metall. 2007, $107,451-462$.

57. Dominy, S.C. Effects of sample mass on gravity recoverable gold test results in low grade ores. Appl. Earth Sci. 2014, 123, 234-242. [CrossRef]

58. Dominy, S.C. Predicting the unpredictable-Evaluating high-nugget effect gold deposits. In Mineral Resource and Ore Reserve Estimation; Australasian Institute of Mining and Metallurgy: Melbourne, Australia, 2014; pp. 659-678.

59. Ehrig, K.; Liebezeit, V.; Macmillan, E. Metallurgical QAQC-who needs it? The Olympic Dam experience. In Proceedings of the Metallurgical Plant Design and Operating Strategies, Perth, Australia, 11-12 September 2017; Australasian Institute of Mining and Metallurgy: Melbourne, Australia, 2017; pp. 31-44.

60. Joint Ore Reserves Committee (JORC). Australasian Code for Reporting of Exploration Results, Mineral Resources and Ore Reserves-The JORC Code; Joint Ore Reserves Committee of the Australasian Institute of Mining and Metallurgy, Australian Institute of Geoscientists and Minerals Council of Australia: Melbourne, Australia, 2012; p. 44.

61. DS3077. Representative Sampling-Horizontal Standard; Danish Standards Foundation: Copenhagen, Denmark, 2013; p. 41.

62. Perez-Barnuevo, L.; Castroviejo, R.; Pirard, E. New perspectives on quantitative textural analysis. In Proceedings of the International Geometallurgy Conference, Brisbane, Australia, 30 September-2 October 2013; Australasian Institute of Mining and Metallurgy: Melbourne, Australia, 2013; pp. 191-197.

63. Lobos, R.; Silva, J.F.; Ortiz, J.M.; Diaz, G.; Egana, A. Analysis and classification of natural rock textures based on new transform-based features. Math. Geosci. 2016, 48, 835-870. [CrossRef]

64. Zhou, J.; Gu, Y. Geometallurgical characterisation and automated mineralogy of gold ores. In Advances in Gold Ore Processing; Elsevier: Amsterdam, The Netherlands, 2016; pp. 95-111.

65. Dominy, S.C.; Platten, I.M.; Xie, Y.; Cuffley, B.W.; O'Connor, L. Characterisation of gold ore from the Nick O'Time shoot (Tarnagulla, Australia) using high resolution X-ray computed tomography. In Proceedings of the International Geometallurgy Conference, Perth, Australia, 15-16 June 2016; Australasian Institute of Mining and Metallurgy: Melbourne, Australia, 2016; pp. 241-254.

66. Miller, J.D.; Lin, C.L. High resolution X-ray micro CT (HRXMT)—Advances in 3D particle characterisation for mineral processing operations. In Recent Advances in Mineral Processing Plant Design; Society of Mining, Metallurgy and Exploration: Englewood, CO, USA, 2009; pp. 48-59.

67. Evans, C.L.; Wightman, E.M.; Yuan, X. Quantifying mineral grain size distributions for process modelling using X-ray micro-tomograph. Miner. Eng. 2015, 82, 78-83. [CrossRef]

68. Harraden, C.L.; Berry, R.; Lett, J. Proposed methodology for utilising automated core logging technology to extract geotechnical index parameters. In Proceedings of the International Geometallurgy Conference, Perth, Australia, 15-16 June 2016; Australasian Institute of Mining and Metallurgy: Melbourne, Australia, 2016; pp. 114-124.

69. Walters, S. A review of core scanning sensor technologies to support routine geometallurgical logging and spatial characterisation. In Proceedings of the International Seminar on Geometallurgy, Santiago, Chile, 5-7 December 2012; GECAMIN: Santiago, Chile, 2012; pp. 102-103.

70. Vantandoost, A.; Fullagar, P. Characterisation of ore crushability using petrophysical properties. In Proceedings of the International Mining Geology Conference, Perth, Australia, 17-19 August 2009; Australasian Institute of Mining and Metallurgy: Melbourne, Australia, 2009; pp. 119-124.

71. Jackson, L.M.; Parbhakar-Fox, A.; Fox, N.; Cooke, D.R.; Harris, A.C. Intrinsic neutralisation potential from automated drill core logging for improved geoenvironmental domaining. In Proceedings of the Australian Workshop on Acid and Metalliferous Drainage 2017, Burnie, Australia, 20-23 November 2017; University of Queensland: Brisbane, Australia, 2017; pp. 378-392. 
72. Linton, P.; Browning, D.; Pendock, N.; Harris, P.; Donze, M.; Mxinwa, T.; Mushiana, K. Hyperspectral data applied to geometallurgy. In Proceedings of the Geometallurgy Conference, Cape Town, South Africa, 7-8 August 2018; Southern African Institure of Mining and Metallurgy: Johannesburg, South Africa, 2018; pp. 109-120.

73. Huntington, J.; Quigley, M.; Yang, K.; Roache, T.; Young, C.; Roberts, I.; Whitbourn, I.L.; Mason, P. A geological overview of HyLogging $18000 \mathrm{~m}$ of core from the Eastern Goldfields of Western Australia. In Proceedings of the International Mining Geology Conference, Darwin, Australia, 21-23 August 2004; Australasian Institute of Mining and Metallurgy: Melbourne, Australia, 2006; pp. 45-50.

74. Parbhakar-Fox, A.; Lottermoser, B.G. Predictive waste classification using field-based and environmental geometallurgy indicators, Mount Lyell, Tasmania. In Environmental Indicators in Metal Mining; Springer International: Cham, Switzerland, 2017; pp. 157-177.

75. Cracknell, M.J. Image texture quantification from Corescan mineral classifications. In Proceedings of the International Association for Mathematical Geosciences Conference, Perth, Australia, 2-9 September 2017; International Association for Mathematical Geosciences: Houston, TX, USA, 2017; p. 130.

76. Cracknell, M.J.; Parbhakar-Fox, A.; Jackson, L.; Savinova, E. Automated acid rock drainage indexing from drill core imagery. Minerals 2018, 8. Accepted.

77. Mahmoodi, O.; Smith, R.S.; Tinkham, D.K. Supervised classification of down-hole physical properties measurements using neural network to predict the lithology. J. Appl. Geophys. 2016, 124, 17-26. [CrossRef]

78. Hegde, C.; Gray, K. Evaluation of coupled machine learning models for drilling optimization. J. Nat. Gas Sci. Eng. 2018, 56, 397-407. [CrossRef]

79. Kitzig, M.; Kepic, A.; Grant, A. Near real-time classification of iron ore lithology by applying fuzzy inference systems to petrophysical downhole data. Minerals 2018, 8, 276. [CrossRef]

80. Vezhapparambu, V.S.; Eidsvik, J.; Ellefmo, S.L. Rock classification using multivariate analysis of measurement while drilling data: Towards a better sampling strategy. Minerals 2018, 8, 384. [CrossRef]

81. Babaei Khorzoughi, M.; Hall, R. Processing of measurement while drilling data for rock mass characterization. Int. J. Min. Sci. Technol. 2016, 26, 989-994. [CrossRef]

82. Kadkhodaie-Ilkhchi, A.; Monterio, S.T.; Ramos, F.; Hatherly, P. Rock recognition from MWD data: A comparative study of boosting, neural networks and fuzzy logic. IEEE Geosci. Remote Sens. Lett. 2010, 7, 680-684. [CrossRef]

83. Dowd, P.A.; Xu, C.; Coward, S. Strategic mine planning and design: Some challenges and strategies for addressing them. Min. Technol. 2016, 125, 22-34. [CrossRef]

84. Dunham, S.; Vann, J. Geometallurgy, geostatistics and project value-Does your block model tell you what you need to know. In Proceedings of the Project Evaluation Conference, Melbourne, Australia, 19-20 June 2007; Australasian Institute of Mining and Metallurgy: Melbourne, Australia, 2007; pp. 189-196.

85. Carrasco, P.; Chilès, J.-P.; Seguret, S. Additivity, metallurgical recovery and grade. In Proceedings of the International Geostatistics Congress, Santiago, Chile, 1-5 December 2008; GECAMIN: Santiago, Chile, 2008; pp. 237-246.

86. Deutsch, C.V. Geostatistical modelling of geometallurgical variables-Problems and solutions. In Proceedings of the International Geometallurgy Conference, Brisbane, Australia, 30 September-2 October 2013; Australasian Institute of Mining and Metallurgy: Melbourne, Australia, 2013; pp. 7-15.

87. Deutsch, J.L.; Palmer, K.; Deutsch, C.V.; Szymanski, J.; Etsell, T.H. Spatial modelling of geometallurgical properties: Techniques and a case study. Nat. Resour. Res. 2016, 25, 161-181. [CrossRef]

88. Muhammad, K.; Glass, H.J. Short-scale variability and uncertainty during mineral resource estimation using a novel fuzzy estimation technique. Geostand. Geoanal. Res. 2011, 35, 369-385. [CrossRef]

89. Sepulveda, E.; Dowd, P.A.; Xu, C.; Addo, E. Multivariate modelling of geometallurgical variables by point projection. Math. Geol. 2017, 49, 121-143.

90. Addo, E.; Metcalfe, A.V.; Chanda, E.K.; Sepulveda, E.; Assibey-Bonsu, W.; Adeli, A. Prediction of copper recovery from geometallurgical data using D-vine cupolas. In Proceedings of the Geometallurgy Conference, Cape Town, South Africa, 7-8 August 2018; Southern African Institute of Mining and Metallurgy: Johannesburg, South Africa, 2018; pp. 75-88.

91. Alruiz, O.M.; Morell, S.; Suazo, C.J.; Naranjo, A. A novel approach to the geometallurgical modelling of the Collahuasi grinding circuit. Miner. Eng. 2009, 22, 1060-1067. [CrossRef] 
92. Powell, M.S. Utilising orebody knowledge to improve comminution circuit design and energy utilisation. In Proceedings of the International Geometallurgy Conference, Brisbane, Australia, 30 September-2 October 2013; Australasian Institute of Mining and Metallurgy: Melbourne, Australia, 2013; pp. 27-35.

93. Navarra, A.; Grammatikopoulos, T.; Walters, K.E. Incorporation of geometallurgical modelling into long-term production planning. Miner. Eng. 2018, 120, 118-126. [CrossRef]

94. Fox, N.; Parbhakar-Fox, A.; Lottermoser, B.G. Critical and deleterious metal deportment in sulfidic waste rocks, Baal Gammon, north Queensland. In Proceedings of the International Geometallurgy Conference, Perth, Australia, 15-16 June 2016; Australasian Institute of Mining and Metallurgy: Melbourne, Australia, 2016; pp. 173-182.

95. Dold, B. Acid rock drainage prediction-A critical review. J. Geochem. Explor. 2016, 172, 120-132. [CrossRef]

96. Parbhakar-Fox, A. Predicting waste properties using the geochemistry-mineralogy-texture-geometallurgy approach. In Environmental Indicators in Metal Mining; Springer International: Cham, Switzerland, 2017; pp. 73-96.

97. Parbhakar-Fox, A.; Fox, N.; Jackson, L. Geometallurgical evaluations of mine waste-An example from the old tailings dam, Savage River, Tasmania. In Proceedings of the International Geometallurgy Conference, Perth, Australia, 15-16 June 2016; Australasian Institute of Mining and Metallurgy: Melbourne, Australia, 2016; pp. 193-204.

98. Babel, B.; Penz, M.; Schach, E.; Boehme, S.; Rudolph, M. Reprocessing of a southern Chilean Zn tailing by flotation-A case study. Minerals 2018, 8, 295. [CrossRef]

99. Johnson, D.B. The evolution, current status, and future prospects of using biotechnologies in the mineral extraction and metal recovery sectors. Minerals 2018, 8, 343. [CrossRef]

100. Benndorf, J.; Buxton, M.W.N. Sensor-based real-time resource model reconciliation for improved mine production control-A conceptual framework. Min. Technol. 2016, 125, 54-64. [CrossRef]

(C) 2018 by the authors. Licensee MDPI, Basel, Switzerland. This article is an open access article distributed under the terms and conditions of the Creative Commons Attribution (CC BY) license (http:/ / creativecommons.org/licenses/by/4.0/). 